NBER WORKING PAPER SERIES

\title{
PARENTAL LEAVE AND CHILDREN'S SCHOOLING OUTCOMES: QUASI-EXPERIMENTAL EVIDENCE FROM A LARGE PARENTAL LEAVE REFORM
}

\author{
Natalia Danzer \\ Victor Lavy \\ Working Paper 19452 \\ http://www.nber.org/papers/w19452 \\ NATIONAL BUREAU OF ECONOMIC RESEARCH \\ 1050 Massachusetts Avenue \\ Cambridge, MA 02138 \\ September 2013
}

We benefited from valuable comments from Jonathan Wadsworth, René Böheim, Andrew Clark, Alexander M. Danzer, Peter Dolton, Analía Schlosser, Christian Dustmann, Uta Schönberg, and Anna Vignoles and participants at the EALE 2012, EEA 2012, ESSLE 2012, RES 2013 and SOLE 2013. The views expressed herein are those of the authors and do not necessarily reflect the views of the National Bureau of Economic Research.

NBER working papers are circulated for discussion and comment purposes. They have not been peerreviewed or been subject to the review by the NBER Board of Directors that accompanies official NBER publications.

(C) 2013 by Natalia Danzer and Victor Lavy. All rights reserved. Short sections of text, not to exceed two paragraphs, may be quoted without explicit permission provided that full credit, including $\odot$ notice, is given to the source. 
Parental Leave and Children's Schooling Outcomes: Quasi-Experimental Evidence from a Large Parental Leave Reform

Natalia Danzer and Victor Lavy

NBER Working Paper No. 19452

September 2013

JEL No. J13,J22,J24

\begin{abstract}
$\underline{\text { ABSTRACT }}$
This paper investigates the question whether long-term human capital outcomes are affected by the duration of maternity leave, i.e. by the time mothers spend at home with their newborn before returning to work. Employing RD and difference-in-difference approaches, this paper exploits an unanticipated reform in Austria which extended the maximum duration of paid and job protected parental leave from 12 to 24 months for children born on July 1, 1990 or later. We use test scores from the Austrian PISA test of birth cohorts 1990 and 1987 as measure of human capital. The evidence suggest no significant overall impact of the extended parental leave mandate on standardized test scores at age 15, but that the subgroup of boys of highly educated mothers have benefited from this reform while boys of low educated mothers were harmed by it.
\end{abstract}

\author{
Natalia Danzer \\ ifo Institute \\ Labour Market Research and Family Economics \\ Poschingerstraße 5 \\ 81679 Munich \\ Germany \\ danzer@ifo.de \\ Victor Lavy \\ Department of Economics \\ Hebrew University of Jerusalem \\ Mount Scopus \\ Jerusalem 91905 \\ ISRAEL \\ and University of Warwick, England \\ and also NBER \\ msvictor@mscc.huji.ac.il
}




\section{Introduction}

This paper investigates whether prolonged paid and job protected parental leave has effects on the offspring's cognitive development. The potential channel is reduced maternal employment in the first years of a child's life that has likely increased maternal time for childrearing. In many industrialized countries, the provision of parental leave is one of the main policy instruments aimed at helping young families reconcile working life with family life. This topic has become increasingly important and prominent in the public debate as female labor force participation rates have been growing over the past decades in many industrialized countries. While proponents of (more generous) parental leave entitlements assert positive consequences for the health and well-being of children and their mothers as well as for the position of women in the workplace, opponents fear that parental leave mandates diminish market flexibility, thereby leading to inefficiencies and lower rates of employment growth (Ruhm 1998, 2000).

The lack of an academic and societal consensus about the potential effects of parental leave on maternal labor market performance and on the development of new-borns is also partly reflected in the large cross-country variation in the generosity of parental leave entitlements in terms of duration of job protection and income replacement level. ${ }^{1}$ Since the length of the granted parental leave is relevant for the return-to-work decision, these crosscountry differences in legislation help to explain why new mothers in some countries return to work much sooner and spend less time at home with their child compared to mothers in other countries (Ruhm 2000; Tanaka 2005).

Overall, previous empirical studies in psychology and economics have produced mixed evidence regarding the impact of early maternal employment on child outcomes. If anything, the majority of studies seem to support the hypothesis that the labor force participation of mothers during their children 's first year of life has potentially adverse effects on their subsequent development (Ruhm 2008). In addition, there is some indication for heterogeneous effects across subgroups: children from higher socio-economic backgrounds are potentially more likely to be negatively affected by maternal employment, while children from low income families might benefit if maternal employment raises family income (Currie 2005). Hence, depending on the specific design of the laws regarding the length of granted leave, the income replacement level during the leave period as well as the medium- to long-

\footnotetext{
${ }^{1}$ For instance, the US federal Family and Medical Leave Act (FMLA) from 1993 grants a maximum duration of unpaid, job protected leave of 12 weeks (Berger, Hill and Waldfogel 2005). The FMLA regulations apply to only about half of the female workforce; parental leave for the other half is determined in individual employer regulations. In contrast, most European countries provide much longer durations of job protected maternity and parental leave (some of which is even compulsory) with partial or full income compensation (Neyer 2003).
} 
term labor market consequences for the mother, parental leave mandates might affect child outcomes through time effects (more maternal time investments) and potentially through income effects (if household income is reduced due to foregone wage earnings of the mother in the short-run and potentially in the long-run).

The difficulty in estimating the causal effect of early maternal employment on child development is that maternal employment, fertility behaviour and the timing of labor market re-entry after childbirth are choice variables and might be driven by unobserved mother or child characteristics (e.g., ability, fertility and work preferences, role models, regional differences in availability and costs of alternative child care). If particular types of women return to work sooner than others, differences in child outcomes between these groups of mothers might reflect differences in maternal characteristics and intergenerational transmission of ability rather than the causal effect of maternal employment. Reverse causality might be an additional problem, since certain health conditions of a child are likely to impede its mother's return to work.

This study analyses the effects of duration of maternal time at home on long-term cognitive child outcomes in Austria by using an unexpected and unanticipated policy reform that extended the maximum duration of job protected and paid parental leave by twelve months for all eligible mothers giving birth on July 1, 1990 or afterwards. Employed women having a child before this cut-off date were only eligible for job protected and paid parental leave until the child $\mathrm{e}$ first birthday while those giving birth afterwards were granted parental leave until the child's second birthday. The reform had a strong impact on the time new mothers stayed at home before returning to work since (a) female labor force participation in Austria in 1990 was already comparatively high, (b) most employed women generally satisfied the eligibility criteria, (c) take-up rates were extremely high and (d) most mothers exhausted the full duration of their leave entitlements (about 80 percent of mothers) (Lalive and Zweimüller 2009; Lalive, Schlosser, Steinhauer and Zweimüller forthcoming). However, although the reform caused mothers to substantially delay their return to work in the shortrun, it did not adversely affect medium- or long-run employment and earnings of mothers (Lalive and Zweimüller 2009; Lalive, Schlosser, Steinhauer and Zweimüller forthcoming).

The aim of this paper is to assess the effect of this twelve-months expansion of paid and job-protected parental leave on cognitive skills of affected children, measured at age 15 by test scores from standardized assessments in mathematics, reading and scientific literacy from the international PISA study (Programme for International Student Assessment). The main empirical strategy is based on a Regression Discontinuity (RD) and a related Difference- 
in-Differences (DID-RD) which exploit the variation in the duration of parental leave created by the specific cut-off date of the reform. ${ }^{2}$ Specifically, we first compare differences in average test scores of children born shortly before and shortly after the reform (born in May/June 1990 versus July/August 1990, respectively). Secondly, we compare these differences with the test score differences in a control year in which there was no reform (children born in May/June 1987 versus July/August 1987). The inclusion of an additional pre-reform control year is motivated by the fact that outcome comparisons across birth months within a given year could be confounded by season of birth or simple age effects (older children being more potentially advantaged at any given test date).

This study contributes to the existing literature in several ways: First, in comparison to the previous quasi-experimental studies, the Austrian reform assessed in this paper is by far the most extensive and generous as it offered 12 additional months of paid and job protected leave and might thus have a stronger impact on child outcomes. Moreover, only a few papers have assessed the effect of maternal care during the child's second year of life. Second, in contrast to the study for Germany by Dustmann and Schönberg (2012) which comes closest to the Austrian case in terms of cultural and institutional background, this analysis contains information on parental background and can thus distinguish between heterogeneous effects across subgroups, a distinction to be shown as very important. Third, the analysis sheds light on the causal relationship between maternal employment in the first years of the child"s life and the child's cognitive development in a country where most non-parental child care of under three-year-olds is provided informally, for instance, by grandparents, instead of formal day care centres (in contrast to countries like Sweden and Denmark where children participate in formal care-centres already at very young ages). Against this background, the reform most likely caused a replacement of informal care through maternal care, which might have different implications than switching from formal to maternal care.

The overall effect of this large parental leave extension on test scores for the pooled sample of all children is close to zero and statistically insignificant, in line with most of the previous quasi-experimental studies from other countries. However, the subgroup analyses by maternal education and child gender points to significant positive reform effects for children

\footnotetext{
${ }^{2}$ The majority of previous studies dealt with the endogeneity problem of the maternal return-to-work decision by including as pre-birth controls, by estimating family fixed effects models and comparing sibling differences, by implementing propensity score matching or by employing instrumental variable techniques (Blau and Grossberg 1992; Currie 2005; Almond and Currie 2011; Hill, Waldfogel, Brooks-Gunn and Han 2005). As Currie (2005) notes, each of these studies has severe limitations for causal inference and conclusions drawn from single studies have to be put in specific context and compared to results using other methods. A few recent papers try to tackle the identification problem by exploiting exogenous changes in parental leave mandates (Baker and Milligan (2010, 2011) focus on Canada, Carneiro, Løken and Salvanes (2010) on Norway, Dustmann and Schönberg (2012) on Germany, Liu and Nordstrom Skans (2010) on Sweden, Würtz Rasmussen (2010) on Denmark).
} 
of highly educated mothers, especially for boys. In contrast, schooling outcomes of children from lower educated mothers seem to have been harmed (boys have lower test scores and girls have a higher likelihood of being in a lower grade). Hence, in an institutional setting with no formal child care system for very young children, early maternal employment of highly educated women might have detrimental effects for their offspring. To what extent such potential negative effects can be mitigated or reversed through a high-quality formal day care system is an open question.

The paper is organized as follows: the next section introduces the underlying theoretical framework and highlights and compares the findings and setup of previous quasiempirical studies of early maternal employment on child outcomes. This is followed by an overview of the institutional background in Austria in Section 3. The section includes details of the Austrian reform as well as a summary of findings from previous studies which evaluated this reform with respect to labor market and fertility outcomes. Section 4 explains the identification strategy and discusses critical assumptions and empirical challenges. Section 5 describes the data and outcome variables. The results of the main specification are presented and discussed in Section 6, while Section 7 contains several robustness checks and sensitivity analyses. Section 8 concludes.

\section{Parental Leave, Maternal Employment and Child Development}

\subsection{The role of maternal employment in the cognitive ability production function}

It is helpful to structure the discussion and analysis of potential effects of maternal employment on child outcomes using the following cognitive ability production function (Bernal and Keane 2011; Dustmann and Schönberg 2012).

$$
Y_{i t}=Y_{i t}\left(T_{i t}, G_{i t}, C_{i t}, F_{i t}, P_{i t}, \omega_{i}\right)
$$

Cognitive ability of child $i$ at age $t\left(Y_{i t}\right)$ is determined by several inputs, namely maternal (parental) time investment, $\mathrm{T}$, up through age $t$, market-purchased goods and services other than non-parental child care, $G$, which depend on family income (examples are quality of housing, additional educational material, nutrition, health expenditure), time investment through non-parental caregivers, $C$, (i.e. time in non-parental child care), any direct effect of family composition, F, e.g. number of siblings (interaction between siblings; quantity-quality trade-off), birth order, time intervals between siblings, public investments in children and child development, P, (e.g., early child development programmes, public child care facilities and schools, state child health programmes and health insurance) and an idiosyncratic ability endowment, $\boldsymbol{\omega}$, e.g., through intergenerational transmission of genes. As 
the function differentiates between different child ages it allows for varying effects of certain inputs at particular stages of child development.

In this framework, there is a clear trade-off between maternal time investment and maternal earned income which could be used to buy market-based inputs. It is possible that the reduction in maternal time inputs of working mothers can be at least partly compensated by other goods (e.g., health investments, better nutrition) or by higher quality time investments of other caregivers. Generally though, the time-income trade-off can be mitigated to the extent that mothers receive compensating parental leave payments while on leave.

Several potential mechanisms through which increased maternal time might positively affect child development are discussed in the literature. One is prolonged breastfeeding which could lead to better health outcomes of children (Baker and Milligan 2008). ${ }^{3}$ Increased maternal care time might improve children's cognitive development by improving their health, for example, by better monitoring of their health status and more timely doctor visits (Berger, Hill and Waldfogel 2005), by preparing healthier meals and lowering risk of injuries and infectious disease (Morrill 2011). Early maternal employment, especially when exceeding 10 hours per week, might also negatively influence the attachment of mother and child and might lead to children 's behavioural problems (Brooks-Gunn, Han and Waldfogel 2002). It is also possible that the physical burden of market-based work leaves mothers with less energy for stimulating and nurturing their children (Ruhm 2004; Waldfogel, Han and Brooks-Gunn 2002). Conversely, a prolonged absence from work might raise the risk of social detachment and of depressions by mothers who stay at home, which in turn lowers the quality of maternal time and might have adverse effects for children (Baum II 2003). ${ }^{4}$

\subsection{Empirical evidence}

All recent studies exploit an unexpected extension of the granted parental leave duration which significantly increases the time mothers stay at home before returning to work after childbirth. ${ }^{5}$ Most of these studies find either no or only negligible effects of prolonged parental leave on cognitive child outcomes. One exception is Carneiro, Løken and Salvanes (2010) who find for Norway significant positive effects of prolonged maternal time at home during the childes first year on medium-run schooling achievement, IQ measures and height. The effects are stronger for children of mothers with low educational attainment. However,

\footnotetext{
${ }^{3}$ However, despite a significant impact of prolonged parental leave entitlements on breastfeeding duration in Canada, most of Baker and Milligan se $\mathrm{s}$ (2008) results do not reveal any positive health effects for children.

${ }^{4}$ In this simplified framework we implicitly hold partner's labour supply and child care input constant. This assumption is less restrictive in countries where the bulk of parental child care is traditionally supplied by the mother and family life follows the ,male bread-winner model ${ }^{\mathrm{ee}}$ as in Austria in 1990.

${ }^{5}$ See Table A1 in the Online Appendix for a summary of these studies and their findings.
} 
Liu and Nordstrom Skans (2010) report for Sweden a zero average effect based on the whole sample but positive effects for children of better-educated mothers. Interestingly, we in this study also find zero average effect but large and significantly positive effect for children of highly educated mothers. In order to reconcile these seemingly contradictory findings it is important to highlight the essential differences between these studies which complicate straightforward comparisons. The analyses vary predominantly with respect to: (1) The affected age group of children: Does the particular extension of parental leave allow women to stay at home longer during the first year of life (e.g., an extension from 8 to 12 months) or does it affect the period when the child is more than two years old? This point is highly relevant if the importance of maternal care varies over the different development stages of the child. (2) The length of the extension: The analysed parental leave extensions vary between six weeks and 18 months. The granted length of the extension is likely to influence the additional time that mothers stay home. If there is a positive effect of maternal time on child outcomes and this effect is increasing with time input, then one would expect differential effects depending on leave duration. (3) The measure of cognitive development and age at its measurement: While some studies focus on short-run effects measured before the first birthday (parent-reported assessments or psychological tests), others compare medium- or long-term outcomes up to age 29 (e.g., using completed educational attainment). (4) Different institutional environments: There are strong differences across countries (and over time) in terms of prevailing non-parental child care arrangements (formal centre-based or informal care by relatives) which determines the type of care likely to be substituted by prolonged maternal care. (5) The type of reform and any indirect effects on other supposedly relevant determinants of child outcomes like income and fertility: e.g., does the reform expand the duration of fully, partly and/or unpaid leave? These indirect effects could alter the (opportunity) costs of children and also enhance or change the ,quantity-quality ${ }^{\text {ee }}$ trade-off. (6) The precision of the data and the estimations: Can eligible mothers be identified (only possible in the Norwegian study) or can children be linked to parents? Are the studies based on representative surveys or administrative datasets? (7) The estimation strategies: the exact implementation of the DID and RD estimations differs across studies as do the control groups.

To sum up, the institutional background and the details of the reforms vary widely across countries and seem to play an important role for the effect of parental leave on child outcomes. In terms of institutional and cultural set-up, Austria comes closest to Germany, while the type of reform (paid leave extension between the childes first and second birthday) is more similar to the evaluated reform in Sweden where, however, participation rates of one- 
to two-year-olds in formal child care are very high. Nevertheless, the reform in Sweden led only to a three months extension of parental leave, while in Austria the extension comprised 12 months. This way the analysis in this paper helps to shed more light on the influence of maternal employment beyond the child's first birthday when formal day care for this age group is generally not available. Furthermore, the Austrian reform is unique in that it involves an exceptionally long extension of paid parental leave.

\section{Institutional setting and background}

The history of parental leave in Austria dates back to 1957 when working women became entitled to an unpaid, but job protected leave of up to six months on top of the paid mandatory maternity leave of 12 weeks, making Austria the first country in Europe to introduce parental leave (Neyer 2003). ${ }^{6} 1974$ saw an introduction of a monthly flat-rate cash benefit to all mothers on parental leave. In 1990, the amount of the regular flat-rate parental leave payment was about 340 Euros per month corresponding to 31 (40) percent of gross (net) median female earnings (Lalive and Zweimüller 2009).

The empirical analysis will exploit a quasi-experiment that was created by the amendment to the parental leave legislation that came in effect on July 1, 1990 (Karenzurlaubserweiterungsgesetz, June 27, 1990, BGBl. Nr. 408/1990). The main aspect of this reform was the extension of the maximal duration of the optional paid and job protected leave from the child ${ }^{\text {ee }}$ first up to the child s second birthday. ${ }^{7}$ This extension was only granted to mothers whose children were born on or after the cut-off date of July 1, 1990. There were no ,transition rules ${ }^{e e}$ allowing mothers who gave birth before July 1, 1990 to benefit from the new regulations. This increase of 12 months of paid and job protected parental leave is much larger than any of the comparable reforms that took place in other countries and that have been evaluated in terms of child outcomes. The reform was announced and implemented only shortly before it came into effect. Therefore it was not possible for parents to adjust their fertility timing in order to take advantage of the more generous parental leave regime (i.e. there were no anticipatory fertility effects).

The fact that the duration of the leave entitlement before and after the reform in Austria was actually binding and thereby exogenously determining the minimum length of

\footnotetext{
${ }^{6}$ Fathers became eligible for parental leave only as of January 1, 1990. Their entitlement to parental leave was conditional on the mother meeting all eligibility criteria. The take-up rate of parental leave of fathers remained close to zero during the 1990s (0.2 percent in 1990, 1 percent in 1997; BMUJF 1999).

${ }^{7}$ In Austria, in 1990, working mothers were subject to a compulsory maternity leave of 8 weeks before and after delivery (job protected leave with 100\% replacement of the average net earnings of the proceeding 13 weeks). Following this compulsory maternity leave, mothers were entitled to a job protected and paid leave up to the child 'es first (second) birthday for those born before (after) July 1, 1990.
} 
leave take-up has been demonstrated by Lalive and Zweimüller (2009) and Lalive, Schlosser, Steinhauer and Zweimüller (forthcoming). Overall, the reform has had a significant impact on the time mothers take parental leave after birth. Only about ten percent of mothers return to work immediately after the end of the mandatory maternity leave, i.e. two months after childbirth, and this pattern holds generally true before and after the reform (see Figure 1, Lalive and Zweimüller 2009). ${ }^{8}$ The figure reveals also a jump of roughly 20 percentage points at the time when the legal leave entitlement expires (at 12 months before the reform and at 24 months after the reform). The reform reduced the short term (within two years) return to work by approximately 35 percentage points. The average duration of parental leave take-up and receiving benefits (after mandatory maternity leave) increased from 10 to 20 months and most mothers exhaust the full duration of their leaves (Lalive, Schlosser, Steinhauer and Zweimüller forthcoming; Lalive and Zweimüller 2009). A rough estimate of the overall share of mothers who were eligible for parental leave in 1990 can be attained by calculating the share of mothers on mandatory maternity leave among all mothers. For 1990, this figure is about 77 percent (the corresponding figure in 1987 is 73.8 percent). ${ }^{9}$ Estimated parental leave take-up rates of eligible mothers range between 93 and 96 percent (Kreimer 2002).

Despite the substantial changes in return-to-work behaviour, there are no mediumterm effects on alternative labor market outcomes like average number of months in employment or earnings per month (Lalive and Zweimüller 2009). Even though in the shortrun post-reform mothers work significantly fewer months on average and have lower earnings than pre-reform mothers, there are no significant differences in these outcomes after ten years.

The reform had also a positive and significant impact on fertility outcomes in the short (within three years after the previous birth) and medium-run (after ten years) (Lalive and Zweimüller 2009). However, high-wage mothers seem to have reacted to the extended leave period mainly by changing the spacing between births, but not overall fertility (reducing very short birth intervals and longer intervals at the same time), while low-wage mothers have additionally increased the total number of births in the next ten years. These heterogeneous fertility effects play an important role for the interpretation of our empirical results.

\subsection{Possible effects of the Austrian reform on child outcomes}

There seem to be two potential channels through which the 1990 parental leave extension in Austria could have affected child development: first, a ,quality channele ${ }^{\text {ee }}$ which works through the potentially superior quality of maternal care as opposed to alternative,

\footnotetext{
${ }^{8}$ See Figure A 1 in the Online Appendix.

${ }^{9}$ Calculations are based on numbers in the Austrian Family Report 1999 (BMUJF 1999), p. 152-157.
} 
informal forms of child care, and second, the ,fertility channele, which works through changes in the fertility behaviour, i.e. the number of children and the spacing between births.

As noted, the parental leave reform in 1990 significantly raised the time new mothers stayed at home after childbirth between the child's first and second birthday, but it did not affect medium- to long-run income and labor market outcomes of the average mother. Thus, it is unlikely that the reform exerted a negative income effect on child outcomes driven by medium- to long-term income losses; if anything, the leave extension generated a relatively small and only short-term income loss caused by foregone earnings during the additional leave months. ${ }^{10}$ At the time of the reform the prevailing form of child care for children under two years of age was almost exclusively informal care provided by grandparents or other persons. ${ }^{11}$ Under the hypothesis that maternal care is superior to informal care for very young children, one would expect that the prolonged parental leave period had a positive impact on child outcomes. This could be especially true for better educated mothers if they are able to provide higher quality and more, productive ${ }^{e e}$ maternal care, for instance, through better access to knowledge on how to foster cognitive development of children (Grossman 2006).

However, the reform may also alter the fertility behaviour of parents. If shorter spacing between births reduces the time and material resources that are allocated to each child, this effect could have negative implications for child development and cognitive outcomes. On the contrary, if the relation between spacing and child outcomes is non-linear, a positive effect of the reduction in extremely short birth intervals could outweigh a negative effect from the average reduction in spacing. If the reform increased the total number of births per woman, this could work in the opposite direction and diminish or reverse a potentially positive time effect.

\section{Empirical approach}

Given the unexpected and strict implementation of the prolonged parental leave period for all children born on July 1, 1990 or later, it is possible to use a Regression Discontinuity methodology and also a Difference-in-Differences analysis based on this RD setup (RD-DID)

\footnotetext{
${ }^{10}$ However, for those women who would not have returned to work after the child's first birthday under the old regime anyways, the prolonged parental leave payments might have implied a gain in short term income as these mothers would not have earned any income during the second year. Furthermore, it is difficult to assess to what extent this short-term income loss from working mothers translates into a potentially negative income shock for the child: if non-parental child care is costly, a fraction of the motheres earned income will be spent on child care and it is not clear whether the remaining amount of maternal income is actually larger or smaller than the parental leave payments. Only if the reform leads to a significant short-term income loss, there might be negative income effects which could work against any positive time effect.

${ }^{11}$ Only about 2.5 percent of children aged zero to two were enrolled in formal day care (own calculations of gross enrolment rates based on birth numbers and children in formal child care; official statistics on early child care are recorded since 1995).
} 
to identify the effect of extended maternal care on child outcomes. ${ }^{12}$ The RD-DID regression specifications that we estimate are the following:

$$
\begin{aligned}
& y_{i}=\alpha+\beta_{1} \text { Post June }+\beta_{2} b c 1990+\beta_{3} \text { Post June } * b c 1990+\theta_{m} \text { birth month }+\varepsilon_{i} \\
& y_{i}=\alpha+\beta_{1} \text { Post June }+\beta_{2} b c 1990+\beta_{3} \text { Post June } * b c 1990+\theta_{m} \text { birth month }+\mu X+\varepsilon_{i}
\end{aligned}
$$

$\boldsymbol{y}_{\boldsymbol{i}}$ is the measure for cognitive child outcome (i.e. test scores from standardized tests), Post June is a dummy indicator for children whose birthday is on or after July 1 (July December) and the coefficient $\boldsymbol{\beta}_{\mathbf{1}}$ captures all possible permanent and general differences between children born in the first and the second half of a given year; bc1990 is a dummy indicator for the birth cohort 1990; the interaction effect between Post June and bc1990 identifies all children whose mothers were affected by the reform and eligible to a longer parental leave $-\boldsymbol{\beta}_{\mathbf{3}}$ is the coefficient of interest and measures the treatment effect; to account for possible season of birth effects as well as age effects the regressions include a set of birth month dummy variables. To control for possible differences in sample composition over time, equation (4.3) contains additionally a set of parental and other background characteristics $(X)$.

If the assignment into treated (=post reform; 24 months PL) and control group (=pre reform; 12 months PL) is ,as good as randome, a simple representation of the estimated treatment effect $\boldsymbol{\beta}_{\mathbf{3}}$ (estimated by OLS) is

$$
\beta_{3}=y_{1990, \text { post }}-y_{1990, \text { pre }}-y_{1987, \text { post }}-y_{1987, \text { pre }} .
$$

This is the difference in average cognitive outcomes (test scores) of children born after versus before the reform (whose mothers were eligible to 24 versus 12 months of paid parental leave respectively) less the difference in outcomes of children born before and after July 1, 1987 who were not subject to the reform. The advantage of this RD-DID approach is that potentially confounding systematic differences between children born before and after July 1 which could otherwise exert a bias are differenced out: First, the test scores used in the analysis stem from tests that took place within a certain month (e.g. April) and children born in January 1990 will be about 12 months older at the time of the test than children born in December 1990. If age in itself has a positive effect on outcomes, any potentially positive effects of the reform will be downward biased, since post-reform children are always younger than pre-reform children. Second, there might be systematic season of birth effects affecting the composition of children and their parents over the year. If certain types of couples are more likely to have babies in particular months of the year this might also impact upon the distribution of test scores across birth months.

\footnotetext{
${ }^{12}$ Dustmann and Schönberg (2012) used a similar approach to study the German reform.
} 
An important identifying assumption in this approach is that mothers could not selfselect into treatment or control group. This basically requires that mothers could not manipulate the date of childbirth around the cut-off date of July 1, 1990. Lalive and Zweimüller (1999) provide several arguments and evidence in support of this assumption: first, an assessment of newspaper reports about a potential reform of parental leave duration revealed that the public discussion did not start before November 11, 1989 and that it was not clear until April 5 whether and when such a reform would be implemented. This timing of policy decision and implementation makes anticipatory adjustments to fertility plans highly unlikely, especially when taking into account that successful conception and date of childbirths cannot be perfectly controlled and planned by parents. Furthermore, as also argued by Würtz Rasmussen (2010), it is biologically infeasible to postpone the expected date of delivery with the exception of planned Caesarean sections. However, an analysis of number of births during the days shortly before and after the reform did not indicate a higher density of births on July 1 or the days after (Lalive and Zweimüller 2009).

Another assumption is the common trend assumption which requires seasonal patterns or age effects to be constant across years. The common trend assumption might be problematic if there are changes over time. Certainly, this assumption becomes less restrictive if one limits the sample to children born extremely close to the cut-off date as these children are very similar in age as well as in season of birth. Another advantage of narrowing the window of birth months before and after the reform would be that these children are more likely to face identical kindergarten and schooling regulations and rules, e.g., the Austrian school year typically runs from September to August. Furthermore, their mothers were exposed to similar macroeconomic conditions and labor market developments. However, this strategy would require a very large data set. Unfortunately, the available test scores data base does not meet this criterion. Hence, given the data at hand, there is a trade-off between limiting the analysis on children who are as similar as possible (which would also reduce the likelihood of violating the common trend assumption) and having a sufficiently large sample size. Therefore, we estimate each specification several times while successively narrowing down the window of birth months. ${ }^{13}$

\footnotetext{
${ }^{13}$ Another reason for narrowing the sample window around the cut-off date as much as possible is the proximity of the reform cut-off date to the Austrian school entry cut-off date. All children having their sixth birthday before September 1 are obliged to start school in the same year (typically at the beginning of September). However, until 1999, enforcement of this school entry cut-off date was not strict, conceding some discretionary power to parents regarding the decision whether their child was ,ready ${ }^{\text {ee }}$ for school or whether it should start one year later. A comparison of the distribution of children in lower than regular grades across birth months for the cohorts 1990 and 1987 (PISA data 2006 and 2003) reveals that this phenomenon is relatively consistent over time which is an important prerequisite for our RD-DID estimation strategy (figures available by the authors upon request).
} 
Since the data neither allow identifying children whose mothers were actually eligible for the more generous parental leave entitlements nor contain information on actual duration of leave taking of mothers, the estimated effect will represent the intention-to-treat effect of the reform, i.e., the reduced form effect of being eligible to 24 instead of 12 months of parental leave. This intention-to-treat effect will be a lower bound estimate of the effect of prolonged parental leave and maternal care on child outcomes, since it is estimated on the full sample including children of mothers who did not change their behaviour because of the reform. This latter group consists of non-working mothers as well as working mothers, who stop working post-birth for much longer than the granted parental leave period irrespective of the actual legislation, and of mothers who return to work very early irrespective of the generosity of the system, either non-eligible working mothers or working mothers would return to work immediately after the compulsory maternity leave period independent of the additional parental leave provision. Furthermore, the intention-to-treat estimate will represent an overall net effect of the reform combining all possible channels through which the parental leave extension might have affected child outcomes.

In the empirical part we will perform subgroup analyses by educational attainment of the mother for two reasons. First, stratifying the sample by mother's education might yield estimates closer to the actual effect of the reform. Mothers with higher (lower) education have on average higher (lower) labor force participation rates and, hence, a higher (lower) likelihood of parental leave eligibility. We will therefore distinguish between mothers having completed post-secondary or tertiary education, 89 percent of whom participate in the labor force (employed or unemployed) and mothers whose highest educational degree is higher secondary school or less, of whom 78 percent are in the labor force. ${ }^{14}$ We label these groups as High Educ. Mothers and Low Educ. Mothers, respectively. However, apart from the employment channel, we do not expect maternal education to have any differential effect on the likelihood of eligibility, since - conditional on employment - parental leave eligibility was almost universal (Lalive, Schlosser, Steinhauer, Zweimüller forthcoming). Second, as discussed in Section 3, the parental leave extension had heterogeneous effects on fertility and spacing between births of low- and high-wage mothers which in turn might lead to differential child outcomes (quality-quantity trade-off). Furthermore, an analysis of the Austrian time use survey 1992 shows that, all else equal, highly educated mothers devote on average almost one hour more to child care than mothers with compulsory education (Neuwirth 2004). Hence,

\footnotetext{
${ }^{14}$ Numbers calculated based on the Austrian Census from May 1991 (see Table A2 in the Online Appendix).
} 
there might be also quantity differences in time investments between low and high educated mothers (and possibly quality differences).

\section{Data}

We use in this study data from the OECD's Programme for International Student Assessment (PISA) for Austria. The PISA studies from 2006 and 2003 capture the relevant „reform ${ }^{\text {ee }}$ birth cohort born between January and December 1990 as well as the „control ${ }^{\text {ee }}$ birth cohort from 1987. Several important features make the PISA data especially suitable for our analysis: first, the PISA data provide results from standardized tests of cognitive skills in terms of reading, mathematical and scientific literacy. The focus of PISA is less a pure assessment of curriculum based knowledge, but more an evaluation of general skills needed for adult life and of the ability to apply knowledge to real-life problems. Second, the tests are administered to a nationally representative sample of 15-year old students independent of their current grade level in school. In contrast, other international studies like TIMSS and PIRLS assess students in particular grade levels, e.g. $4^{\text {th }}$ and $8^{\text {th }}$ grade, and are thus not representative for a particular birth cohort. Comparisons of outcomes across birth months would be biased if, for example, the propensity of grade retention or early or late school entry differs between children born closer or further away from the school entry cut-off date. Third, the PISA data files contain important student-reported background information on the student (e.g., gender, birth year and month, nationality, attitudes), the student's parents (educational achievement, nationality, occupational information) and the school (e.g., school programme, location, school size, resources).

However, the Austrian PISA data have also several disadvantages: there is no retrospective information on maternal labour market participation at the time of birth which prevents a clear identification of mothers who were truly eligible for parental leave. Moreover, PISA does not contain publicly available information on exact birth dates which prevents any refinement of the analysis beyond the month level.

To increase the cohesiveness of the data for the analysis we first dropped from the sample students whose mothers are highly unlikely to have been eligible for parental leave or affected by the reform. This included children who were not born in Austria and whose mothers were thus unlikely to work in Austria at the time of the reform in 1990. Furthermore, a few observations had missing information on maternal education. A small number of students in schools for children with special needs were also excluded from the sample to 
increase consistency across students and across years, since these children have a completely different curriculum and were administered special test items.

The variables used in the analysis are described in Table 1. The main outcome variables measuring cognitive skills are test scores in mathematics, reading and science. The test scores in each subject are rescaled by the OECD so that the mean across all participating countries is 500 points and the standard deviation is 100 points. ${ }^{15}$ Two other outcome variables are binary variables indicating i) whether a student is in a lower than the regular grade level given his or her birth month and ii) whether the student is enrolled in a school track giving access to university or college education (academic track). ${ }^{16}$ Student ${ }^{\text {ee }}$ level data includes gender, month of birth, an indicator for school location in an urban area, mother's and father's highest completed level of education, and migration status of the family (whether the family speaks German at home and whether mother and father were born in Austria; the base category are non-German speaking families).

The mean values of the outcome variables and variables of the PISA 2006 and 2003 data are presented in Table 1, separately for children born in May and June and for children born in July and August. The evidence in the table show that there are no significant systematic differences between pre- and post-reform children in 2006, which supports the important assumption that the 1990 reform was unexpected and that there was no systematic self-selection of particular types of parents or families across the cut-off date.

\section{Empirical results}

A first graphical impression of the RD-DID setup for all three test subjects is provided in Figure 1.The figure plots average test scores by birth month together with fitted lines of the predicted test scores to the left and to the right of the reform cut-off date (July 1, vertical line) for both, the reform cohort 1990 and the control cohort 1987. Overall, there is a slightly negative trend in average test scores across birth months which could be explained by possible age effects as discussed earlier. Crucial, however, is the fact that there is no jump in test results for children from the 1990 reform cohort born immediately before and after the reform cut-off date. Indeed, for all three test subject, the predicted fits to the left and to the

\footnotetext{
${ }^{15}$ To ease comparison of results across survey years, the test results were rescaled such that the reading and mathematics reporting scales of 2006 are equal to those in 2003. The test results in science are rescaled such that the mean is 500 and the standard deviation is 100 for the 30 OECD countries participating in PISA 2006 (see OECD 2009, pp. 157-158). However, any general differences in test scores across years and subjects will be accounted for in the analysis by controlling for years and by running separate regressions for each subject.

${ }^{16}$ In Austria, students are allocated to different educational tracks after the fourth grade (i.e. at age 10 or 11 ) which is relatively early compared to other European countries (Schneeweis and Zweimüller 2009). Starting with grade level nine, a further differentiation into specific tracks takes place.
} 
right of the reform date are continuous at the cut-off, suggesting no effect of the parental leave reform on test scores. This zero finding is substantiated by the virtual overlap of the test scores and fitted lines of the 1990 reform cohort with those of the control cohort from 1987 (except for scientific literacy).

Repeating this graphical analysis separately for male and female students produces the same continuous pattern indicating no reform effect, neither for boys nor for girls. ${ }^{17}$ However, these findings of no average effects for the entire group as well as for the gender subgroups mask quite substantial reform effect heterogeneity with respect to child gender in combination with maternal education. Figure 2 and Figure 3 show the RD-DID graphs for boys and girls, respectively, and differentiate between children of mothers with higher and lower educational attainment. In particular, when focusing on the black fitted line for sons of highly educated mothers born in the reform year 1990 (Figure 2, top panel), it appears that there is a clear positive jump in test scores immediately after the reform. The overall downward sloping curve is simply shifted upward for those children born after the cut-off date. In contrast, the grey fitted lines for the corresponding subgroup of children from the control cohort 1987 are continuous around the cut-off indicating no systematic differences in test scores between children born before and after July 1 in the absence of the parental leave reform. Turning to the lower panel of Figure 2, this pattern is different for sons of mothers with lower educational attainment: the predicted fit for this subgroup shows either no reform effect (mathematics) or a negative, but very small jump in reading and science test scores after the reform. The corresponding grey lines for the 1987 control cohort are once again continuous at the cut-off date. Overall, the graphs in Figure 2 suggest a positive reform effect only for boys of higher educated mothers and a zero or slightly negative effect for sons of less educated mothers. These heterogeneous reform effects with respect to maternal education do not seem to hold for girls, though. None of the separate graphs for girls do show any substantial jumps at the cut-off date (Figure 3).

To test whether the test score gap between June and July children is significantly different from zero, we regress test scores from the three different subjects on a set of birth month indicators with June as the excluded base category (controlling for parental background). The estimated „born in July“e coefficients are reported in Table 2 for separate regressions by subject, maternal education and child gender. The first two columns in Table 2 show the results from the full sample of mothers. As the graphs in Figure 1 suggested the average test scores do not differ significantly between pre- and post-reform children in the full

\footnotetext{
${ }^{17}$ See Figure A2 in the Online Appendix. Separate graphs by maternal education (Figure A3, Online Appendix) reveal a positive jump in test scores at the reform cut-off for children from highly educated mothers.
} 
sample and this applies to all three tested subjects. Furthermore, the estimated coefficients change only marginally after controls for parental background are included in the regression (although standard errors become slightly smaller). Comparing the results by gender (columns 1 and 2, middle and bottom panel) reveals that there might be gender differences as the estimated coefficients for boys tend to be positive (but insignificant), while the estimated coefficients for girls tend to be negative.

Restricting the sample to the subsample of children of higher educated mothers (columns 3 and 4) confirms the graphical impression of a positive effect: the estimated effects become much larger and are significantly different from zero (at the five percent level) for reading and science. The separate analyses by gender reveal that the differences are significantly different from zero only for boys. For completeness, the two columns on the right show the respective results for children of mothers with lower educational attainment. Most of the coefficients have a negative sign implying a decline in test scores after the reform; however, none of these effects is statistically significant.

\subsection{Regression Discontinuity-Difference-in-Differences estimations (RD-DID)}

As a next step, we refine the analysis by estimating RD-DID models in order to take account of potentially confounding age, seasonality and school-entry effects. The results of the main RD-DID estimates of the effect of the parental leave extension on PISA test scores are presented in Table 3 for the full sample (all mothers) and separately by maternal education. The estimation window covers children born two months before and after the reform (May to August). For each of the three samples the first column shows the results without any control variables (columns 1, 3 and 5), while the second column contains results after controlling for background variables to account for potential changes in sample composition across years (and possibly across months). This more refined estimation approach confirms the findings from the simple graphs shown earlier: the treatment effects of the reform (being born post June in the year 1990) are close to zero in the full sample (columns 1 and 2). Adding background controls changes the coefficients slightly, but given the size of the standard errors these differences are not statistically significant. ${ }^{18}$ The average effect on reading test scores is a little bit larger and negative, but still not significantly different from zero.

In contrast to these neutral findings are the results from the regressions based on the subsample of children of mothers with higher education. The average effect for all three test

\footnotetext{
${ }^{18}$ Standard errors were clustered by school programme, school location and gender to account for the fact that test scores of students in the same programme, location and gender are likely to be correlated and not independent of each other.
} 
subjects is significantly positive and of remarkable size, indicating that the extended parental leave period raised test scores by about 22 percent of a standard deviation (a little bit less in mathematics). ${ }^{19}$ It is possible that these differences in results between the full sample and children of highly educated mothers are partly related to the different levels of parental leave eligibility (due to differences in labour force participation rates). More importantly though, the results for this subgroup are more likely to show the pure time and care effect of the parental leave extension, since the reform did not affect overall fertility or labour market success of mothers with higher earnings (proxied here by higher educational attainment). In comparison, the effects for children of mothers with lower education are generally negative and even statistically significant for the reading test scores. Although the fraction of affected mothers in this group is smaller, it seems that these children have not benefited from the reform. Furthermore, the statistically significant negative coefficients suggests that the heterogeneous reform effects with respect to maternal education are not driven by differential levels of parental leave eligibility, but by other mechanisms. For instance, the negative effect could be attributed to the increased levels of fertility of low-wage mothers and to less available resources (time and market goods) per child (i.e. a possible ,quantity-quality ${ }^{\text {ee }}$ tradeoff), to shorter time intervals between births or maybe to a lower quality of maternal time in the sense of ability to foster cognitive child development.

To shed more light on potential gender differences regarding the effects of maternal employment on the cognitive development of children, we run separate regressions for boys and girls (Table 4). Even though sample sizes become rather small in this subgroup analysis, the estimates seem to indicate that boys react more strongly to the reform than girls, especially when looking at those with higher maternal education (columns 3 and 4). While both, post-reform girls and boys, have higher test scores on average, only the coefficients for the boys are statistically significant from zero and are almost three times as large as that for girls (the effect on reading and science test scores for males corresponds to about 0.3 and 0.4 standard deviations). These results would be in line with potential differences in needs and in development between girls and boys at very young ages causing boys to benefit comparatively more from maternal vis-à-vis informal care between the age of one and two. For instance, Brooks-Gunn, Han and Waldfogel (2002) state that boys seem to be more „vulnerable to early stressors ${ }^{e e}$ and react more adversely to non-maternal child care. Similarly,

\footnotetext{
${ }^{19}$ As a further refinement, we add a set of dummy variables for the different school programs (which are highly correlated with different average test scores). As expected, their inclusion helps to increase the precision of the estimates. The treatment effects get larger and more significant. However, due to the potential endogeneity of these variables these results are only reported in the Online Appendix, Table A 3.
} 
two US studies on the effect of early maternal employment on children"s health outcomes find that boys are more adversely affected than girls (Gennetian, Hill, London and Lopoo 2010; Morrill 2011). As before, the results for the pooled sample are rather small and insignificant (columns 1 and 2) and the results for children of mothers with lower educational attainment (columns 5 and 6) show negative coefficients which are even significantly different from zero for boys in some specifications.

Given the trade-off between raising the sample size and the need to keep the estimation window as narrow as possible to reduce the influence of possibly confounding factors, we re-run the regressions symmetrically while gradually reducing the window of included birth months to the left and to the right of the cut-off date (four/three/two months before and after). ${ }^{20}$ The results in Table 5 are reported separately by motheres education. The results for children of mothers with higher education (columns 1 to 3 ) reveal that increasing the sample size symmetrically to the left and to the right of the cut-off leads to positive, but smaller and insignificant coefficients in the pooled sample on boys and girls (top panel). However, the estimated effects for boys remain highly significant and positive. Those for girls become much smaller and even switch signs. The results for children of lower educated mothers become less negative (or more positive) the more months are included in the analysis. For this subgroup, most of the results remain negative and become generally insignificant; the strongest effects are still found for boys. ${ }^{21}$

To test whether these results are influenced by children born after the school-entry cutoff date (September 1), who are thus in lower grade levels than students born before September, we alternatively added further birth months only to the left of the cut-off date, while holding the number of months to the right constant (July and August). ${ }^{22}$ The results change only marginally indicating that the previous results were not confounded by the school-entry cut-off regulation.

\footnotetext{
${ }^{20}$ We also estimated our main RD-DID specification as well as the robustness checks and placebo tests using a one-month window. However, especially for our subsample analyses, the sample sizes became too small to derive solid and meaningful results.

${ }^{21}$ As a rough check of whether the reform effect was mainly due to replacing informal by maternal care, we reestimated the regressions from Table 5 excluding students from Vienna, where the proportion of children aged 02 enrolled in childcare during the 1990s was much higher than in the rest of Austria. The results in Table A 4 (Online Appendix) seem to support this hypothesis: the estimated effects for children of highly educated mothers are slightly larger, while the negative coefficients for sons of low educated mothers get closer to zero. This is what one could expect if the reform implied more of a trade-off between formal versus maternal child care in Vienna with more severe effects for children (especially sons) of mothers with lower education. Excluding this region from the sample should consequently reduce the pronounced negative effect of the reform.

${ }^{22}$ For results, see Table A 5 in the Online Appendix.
} 


\subsection{Difference-in-Difference-in-Differences estimations (RD-DDD)}

The RD-DID estimation strategy assumes that age-related differences across birth months (season-of-birth, age-at-test, school-entry effect) are constant over time or at least over the three years that lie between the two birth cohorts in the PISA waves 2006 and 2003. As a further check, we add the German PISA sample as an additional control group participating in both relevant years without being affected by the Austrian parental leave reform in 1990. We chose Germany as control region as it is very similar to its neighbouring country Austria not only in terms of its schooling and tracking system (Schneeweis and Zweimüller 2009). Both countries are also very close in terms of their child care institutions as well as cultural values and attitudes towards the role of families and mothers (Neyer 2003). Furthermore, the PISA test language in both countries is German.

By including a further control group to the analysis the effect of the parental leave reform on child outcomes will be estimated using a Regression Discontinuity in a triple difference estimation design (RD-DDD). In addition to the previous RD-DID regressions, the regressions contain a further country variable „Austriaa, as well as interaction effects between this country variable and „Post June $e^{e e}$ births and the birth cohort dummy variable ,bc1990"e and the triple interaction term of the „Post June ${ }^{e e}$, ,bc1990“e and „Austria ${ }^{e e}$ dummy variables.

$$
\begin{aligned}
y_{i} & =\alpha+\beta_{1} \text { Post June }+\beta_{2} b c 1990+\beta_{3} \text { Post June } * b c 1990+\beta_{4} \text { Austria }+\beta_{5} \text { Austria } * \\
& \text { bc1990+ } \beta_{6} \text { Austria } * \text { Post June }+\beta_{7} \text { Post June } * b c 1990 * \text { Austria }+ \\
& \theta_{m} \text { birth month }+\mu X+\varepsilon_{i}
\end{aligned}
$$

The OLS estimate of the treatment effect $\boldsymbol{\beta}_{\mathbf{7}}$ now becomes: ${ }^{23}$

$$
\begin{gathered}
\beta_{7}=y_{1990, A U T, p o s t}-y_{1990, A U T, p r e}-y_{1990, G E R, p o s t}-y_{1990, G E R, p r e}- \\
y_{1987, A U T, p o s t}-y_{1987, A U T, p r e}-y_{1987, G E R, p o s t}-y_{1987, G E R, \text { pre }}
\end{gathered}
$$

Table 6 displays the estimated treatment effect of the parental leave reform in Austria based on the RD-DDD specifications. Generally, the RD-DDD results correspond to the previous RD-DID estimates. Children of higher educated mothers seem to have benefited from the parental leave extension - the estimated coefficients are positive for all children, but only significant and larger for boys (the estimated coefficients are slightly larger than the RDDID estimates, corresponding to approximately between 0.4 and 0.7 standard deviations).In contrast, the results for children of lower educated mothers become more negative in the pooled sample of boys and girls and are even statistically significantly for the reading test scores. Splitting the sample into male and female students reveals that this negative effect is

\footnotetext{
${ }^{23}$ AUT indicates Austria; GER indicates Germany.
} 
mainly driven by boys. In contrast to the previous RD-DID results, the RD-DDD estimates for boys now become much larger and more significant. The estimates for the girls are generally not very large (albeit positive) and insignificant. ${ }^{24}$

\section{Further robustness checks and alternative outcome variables}

As a robustness check of our estimates we use only data from PISA 2006 and repeat the RD-DID regressions using German students as control group (instead of Austrian students from the pre-reform year 2003). This estimation strategy replaces the assumption of a common month of birth trend across years by the assumption of a common month of birth trend across regions. Again, the results for the children of higher educated mothers are generally consistent with the main previous findings (see Table 7; the estimated effects for boys become even more significant). ${ }^{25}$ For children of lower educated mothers the estimated effects in the pooled sample remain insignificant. However, the estimated coefficients for boys become insignificant; those of the girls increase in size and become positive in the extended samples (including three or four pre- and post-reform birth months). When using the two-months window sample, these positive effects are much smaller and only marginally significant for scientific literacy. ${ }^{26}$

Table 8 presents the results of two placebo RD-DID analyses using our original RDDID estimation strategy based on the Austrian sample and the 1990 and 1987 birth cohorts, but using May 1, 1990, and September 1, 1990, as pseudo reform cut-off dates. ${ }^{27}$ In each case, the estimations are based on children born two months before and after the pseudo reform date. None of the estimated placebo effects is significantly different from zero for the sample of boys (irrespective of maternal educational background). Generally, this is also true for the subsample of girls (the exceptions are a significantly negative (positive) coefficient for the reading (science) score of daughters from highly educated mothers, columns 2 and 5). Thus, overall, but especially regarding the male subsample, the placebo tests seem to verify that our

\footnotetext{
${ }^{24}$ Re-running the RD-DDD regressions holding the number of post-reform months constant, while extending the number of pre-reform months produces very similar results (see Table A 6, Online Appendix).

${ }^{25}$ To reduce the extensiveness of the tables, we only report results from the subgroup regressions by gender.

${ }^{26}$ In contrast to Austria, the general school-entry cut-off date in Germany for the cohort born in 1990 (same for the 1987 cohort) is June 30, which would coincide with the Austrian parental leave reform cut-off date, July 1. This could potentially lead to a violation of the common trend assumption if this causes a drop in average test scores around this threshold in the German sample. While the RD-DDD regressions accounted for this potential drop by differencing also across years, this might be a problem in the RD-DID regression set up (by artificially raising the ,treatment effect ${ }^{\text {e) }}$.

${ }^{27}$ Due to several data and sample problems we cannot exploit the two other existing PISA waves for Austria from the years 2000 and 2009 for further robustness check and to analyse the common trend assumption (e.g., a biased sampling frame in the Austrian PISA 2000, and a stricter enforcement of the school entry cut-off date that affected the birth cohort tested in 2009 violating the common trend assumption).
} 
main RD-DID results are not confounded by particular patterns in the data and can indeed be interpreted as the causal effect of the parental leave reform.

To better understand potentially underlying mechanisms of our main findings we analyze two alternative schooling outcomes. Using our basic RD-DID setup, we test whether the parental leave extension affects the likelihood that a student is i) in a lower than regular grade level given his or her birth month and ii) enrolled in an academic track school (Table 9). ${ }^{28}$ After all, the estimated treatment effect on test scores might partly be driven by these underlying mechanisms. As regards the school track, the estimated reform effects are very small and not significantly different from zero. The same is true for grade retention in the pooled sample and in the subsample for children of higher educated mothers. However, for children of mothers with lower educational attainment the results suggest that the extended leave significantly increased the likelihood of being in a lower than regular grade level. This effect is significantly positive in the pooled sample of boys and girls, but seems to be particularly driven by the reform effect on girls.

\section{Conclusions}

The objective of this paper is to investigate whether a substantial extension of a paid and job-protected parental leave mandate - from a child's first to its second birthday - has any long-term effects on human capital of children. What makes the Austrian parental leave reform particularly compelling for such a causal analysis is that it was implemented with a strict and unanticipated cut-off date: only those mothers who gave birth to their child on or after July 1, 1990 became eligible for the more generous 24 months parental leave duration. As a consequence of this unexpected cut-off date the allocation of mothers and their children into treatment (24 months parental leave entitlements) and control (12 months parental leave) group was sharp and quasi random. This exogenous discontinuity in parental leave duration helps to control for the problem of the otherwise endogenous return-to-work decision. Another advantage of this particular Austrian reform is that it did not seem to have had any effects on medium or long-term labour market outcomes of mothers and only a small positive effect on fertility of low-wage mothers.

We use mathematics, reading and science test scores from the standardized PISA test at age 15 (using the cohort born in the year of the reform 1990 as well as a control birth cohort born 1987 which was not subject to the parental leave reform). The results of the RD and RD-DID analyses and several robustness checks reveal that there are heterogeneous

\footnotetext{
${ }^{28}$ As PISA data do not contain information grade repetition or age at school entry we cannot disentangle whether a student is in a lower than should-be grade level due to deferred school entry or grade repetition.
} 
effects of the parental leave reform on PISA test scores across subgroups. When using the full sample, the estimates suggest no statistically significant causal effects on cognitive skills. This finding for Austria is in line with the results of most of the studies using changes in parental leave mandates to identify the causal effect of early maternal employment on child outcomes. However, when splitting the sample into two groups of mothers with higher and lower educational attainment, interesting findings emerge: for the children of higher educated mothers, we find significantly positive effects of the parental leave extension on the PISA test scores at age 15. This positive result is especially driven by the large and significant effect on boys. We also find negative reform effects for boys of mothers with lower education. These results are in contrast to findings reported in Carneiro, Løken and Salvanes (2010) for Norway where an extension of maternal leave during the first 12 months since birth had positive effect for children of low educated mothers and not effect on others. Furthermore, Liu and Nordstrom Skans (2010) also find positive effects for their assessed parental leave extension in Sweden when restricting the sample to children of mothers with higher education. However, in contrast to Sweden with a well-established formal child care system for undertwo-year olds, the reform in Austria took place at a time when formal childcare for very young children was virtually non-existent. Hence, our empirical results suggest that maternal care of mothers with higher education might be superior to different informal care arrangements for children aged one to two years. The negative effects for children from mothers with lower education might be caused by reduced time and material resources as low wage mothers reacted to the parental leave reform with increased fertility rates and shorter time intervals between births. Our study thus adds unique and policy relevant evidence on heterogeneous effects of a parental leave extension with respect to maternal educational status. The same is true for gender differences: while there exists some evidence of heterogeneous health outcomes of girls and boys with respect to early maternal employment in the empirical literature, the previous evaluation studies of parental leave on cognitive child outcomes have not tested or not found corresponding gender effects. Against this background, the presumably stronger effect of the Austrian parental leave extension on boys points to an interesting aspect which should be explored in more detail in future research. Our empirical results - in particular, those for children from mothers with higher educational background are robust to various sensitivity checks - including triple DID estimates using Germany as an additional control region which was not affected by the 1990 parental leave reform and several placebo tests. 


\section{References}

Almond, Douglas and Janet Currie. 2011. "Human Capital Development Before Age Five." in David Card and Orley Ashenfelter (eds.), Handbook of Labor Economics, Vol. 4b, Chapter 15: 1315-1486.

Baker, Michael and Kevin Milligan. 2008. "Maternal employment, breastfeeding, and health: evidence from maternity leave mandates." Journal of Health Economics, 27 (4): 871887.

Baker, Michael and Kevin Milligan. 2010. "Evidence from maternity leave expansions of the impact of maternal care on early child development." Journal of Human Resources, 45 (1): $1-32$.

Baker, Michael and Kevin Milligan. 2011. "Maternity Leave and Children's Cognitive and Behavioral Development", NBER Working Paper No. 17105

Baum II, Charles L. 2003. "Does Early Maternal Employment Harm Child Development? An Analysis of the Potential Benefits of Leave Taking.” Journal of Labor Economics, 21 (2): 409-448.

Berger, Lawrence M., Jennifer Hill and Jane Waldfogel. 2005. "Maternity Leave, Early Maternal Employment and Child Health and Development in the US." The Economic Journal, 115 (501): F29-F47.

Bernal, Raquel and Michael P. Keane. (2011). "Child Care Choices and Children"s Cognitive Achievement: The Case of Single Mothers.” Journal of Labor Economics, 29 (3): 459512.

Blau, Francine D. and Adam J. Grossberg. 1992. "Maternal Labor Supply and Children's Cognitive Development." The Review of Economics and Statistics, 74 (3): 474-481.

BMUJF. 1999. “Österreichischer Familienbericht 1999 - Band 2, Partnerschaften zur Vereinbarkeit und Neuverteilung von Betreuungs- und Erwerbstätigkeit”; Federal Ministry of Environment, Youth and Family; Austria. [Austrian Family Report 1999 Vol. available

at: http://www.bmwfj.gv.at/Familie/Familienforschung/Seiten/4Familienbericht1999.aspx Brooks-Gunn, Jeanne, Wen-Jui Han and Jane Waldfogel. 2002. "Maternal Employment and Child Cognitive Outcomes in the First Three Years of Life: The NICHD Study of Early Child Care.” Child Development, 73 (4): 1052-1072. 
Carneiro, Pedro, Katrine Løken and Kjell G. Salvanes. 2010. “A flying start? Long Term Consequences of Maternal Time Investments in Children During Their First Year of Life”, IZA Discussion paper No. 5362 (December 2010).

Currie, Janet. 2005. "When Do We Really Know What We Think We Know? Determining Causality”, in Bianchi, Suzanne M., Lynne M. Casper, and Rosalind B. King (eds), "Work, Family, Health and Well-Being." Mahwah, NJ: Lawrence Erlbaum Associates, Chapter 19: 279-296.

Dustmann, Christian and Uta Schönberg. 2012. "Expansions in Maternity Leave Coverage and Children"s Long-Term Outcomes", American Economic Journal: Applied Economics, 4(3): 190-224.

Gennetian, Lisa A., Heather D. Hill, Andrew S. London and Leonard M. Lopoo. 2010. "Maternal employment and the health of low-income young children." Journal of Health Economics, 29 (3): 353-363.

Grossman, Michael. 2006. "Education and nonmarket outcomes." in Hanushek, Eric A. and Finis Welsh, "Handbook of the Economics of Education”, Volume 1, Chapter 10: 577 633.

Hill, Jennifer L., Jane Waldfogel, Jeanne Brooks-Gunn, and Wen-Jui Han. 2005. "Maternal Employment and Child Development: A Fresh Look Using Newer Methods." Developmental Psychology, 41(6): 833-850.

Kreimer, Margareta. 2002. "Paternal Leave" Working paper, available at http://elliscambor.mur.at/pdf/vaeterkarenz.pdf.

Lalive, Rafael, Analía Schlosser, Andreas Steinhauer and Josef Zweimüller. forthcoming.

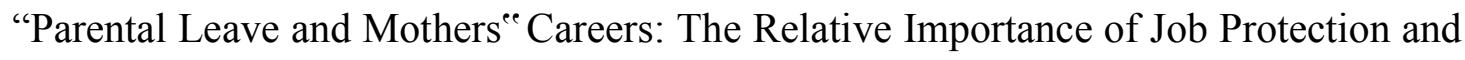
Cash Benefits", Review of Economic Studies, forthcoming.

Lalive, Rafael and Josef Zweimüller. 2009. "How does Parental Leave Affect Fertility and Return to Work? Evidence from Two Natural Experiments." The Quarterly Journal of Economics, 124 (3): 1363-1402.

Liu, Qian and Oskar Nordstrom Skans. 2010. "The Duration of Paid Parental Leave and Children"s Scholastic Performance." The B.E. Journal of Economic Analysis \& Policy, 10(1) (Contributions), Article 3. 
Morrill, Melinda S. 2011. "The effects of maternal employment on the health of school-age children." Journal of Health Economics, 30 (2): 240-357.

Neuwirth, Norbert. 2004. "Parents"e Time, Allocated for Child Care? An Estimation System on Parents "Caring Activities", Austrian Institute for Family Studies Working Paper, No. 46.

Neyer, Gerda R. 2003. "Family policies and low fertility in Western Europe." Journal of Population and Social Security: Population Study, Supplement to Volume 1: 46-93.

OECD. 2009. "PISA 2006 Technical Report", Paris, France. Available at: http://www.pisa.oecd.org/dataoecd/0/47/42025182.pdf

Ruhm, Christopher J. 1998. "The Economic Consequences of Parental Leave Mandates: Lessons from Europe.” The Quarterly Journal of Economics, 113 (1): 285-317.

Ruhm, Christopher J. 2000. "Parental leave and child health." Journal of Health Economics, 19 (6): 931-960.

Ruhm, Christopher J. 2004. "Parental Employment and Child Cognitive Development." Journal of Human Resources, 39 (1): 155-192.

Ruhm, Christopher J. 2008. "Maternal employment and adolescent development." Labour Economics, 15 (5): 958-983.

Schneeweis, Nicole and Martina Zweimueller. 2009. "Early tracking and the misfortune of being young", The Austrian Center for Labor and Economics and the Analysis of the Welfare State, Working Paper No. 0920.

Tanaka, Sakiko. 2005. "Parental Leave and Child Health Across OECD Countries." The Economic Journal, 115 (501): F7-F28.

Waldfogel, Jane, Wen-Jui Han and Jeanne Brooks-Gunn. 2002. "The Effects of Early Maternal Employment on Child Cognitive Development.” Demography, 39 (2): 369392.

Würtz Rasmussen, Astrid. 2010. "Increasing the length of parents' birth-related leave: The effect on children's long-term educational outcomes.” Labour Economics, 17 (1): 91 100. 
Table 1: Mean comparisons of outcomes and characteristics of students born in May/June versus July/August in the reform year 1990 and the control year 1987

\begin{tabular}{|c|c|c|c|c|c|c|c|c|}
\hline \multirow{3}{*}{ Birth months } & \multicolumn{4}{|c|}{ PISA 2006 (birth cohort 1990) } & \multicolumn{4}{|c|}{ PISA 2003 (birth cohort 1987) } \\
\hline & $\begin{array}{l}\text { Pre } \\
\text { reform }\end{array}$ & $\begin{array}{l}\text { Post } \\
\text { reform }\end{array}$ & & & $\begin{array}{l}\text { Pre } \\
\text { reform }\end{array}$ & $\begin{array}{l}\text { Pre } \\
\text { reform }\end{array}$ & & \\
\hline & $\begin{array}{c}\text { May- } \\
\text { June } \\
\text { Mean } \\
(1)\end{array}$ & $\begin{array}{l}\text { July- } \\
\text { Aug. } \\
\text { Mean } \\
(2)\end{array}$ & $\begin{array}{l}\text { Diff. } \\
(2)-(1)\end{array}$ & $\begin{array}{l}\text { Std. } \\
\text { error }\end{array}$ & $\begin{array}{l}\text { May- } \\
\text { June } \\
\text { Mean } \\
(1)\end{array}$ & $\begin{array}{l}\text { July- } \\
\text { Aug. } \\
\text { Mean } \\
(2)\end{array}$ & $\begin{array}{l}\text { Diff. } \\
(2)-(1)\end{array}$ & $\begin{array}{l}\text { Std. } \\
\text { error }\end{array}$ \\
\hline $\begin{array}{l}\text { Mathematics score } \\
\text { (Std. deviation: 92.8) }\end{array}$ & 521.20 & 519.80 & -1.45 & 5.23 & 515.90 & 515.10 & -0.74 & 5.92 \\
\hline $\begin{array}{l}\text { Reading score } \\
\text { (Std. deviation: } 101.1 \text { ) }\end{array}$ & 507.20 & 500.70 & -6.46 & 5.74 & 501.10 & 501.70 & 0.62 & 5.73 \\
\hline $\begin{array}{l}\text { Science score } \\
\text { (Std. deviation: 90.6) }\end{array}$ & 526.90 & 523.70 & -3.18 & 5.09 & 504.40 & 502.50 & -1.87 & 5.65 \\
\hline Retained & 0.21 & 0.34 & $0.13^{* *}$ & 0.03 & 0.25 & 0.33 & $0.08^{* *}$ & 0.03 \\
\hline nic track & 0.54 & 0.52 & -0.02 & 0.03 & 0.46 & 0.51 & 0.04 & 0.03 \\
\hline Male & 0.52 & 0.50 & -0.02 & 0.03 & 0.50 & 0.49 & -0.01 & 0.03 \\
\hline Age in years & 15.92 & 15.75 & $-0.17^{* *}$ & 0.00 & 15.93 & 15.76 & $-0.17^{* *}$ & 0.00 \\
\hline City & 0.41 & 0.41 & -0.01 & 0.03 & 0.34 & 0.35 & 0.01 & 0.03 \\
\hline Metropolitan area & 0.14 & 0.13 & -0.01 & 0.02 & 0.16 & 0.14 & -0.02 & 0.02 \\
\hline Mother"s education: & & & & & & & & \\
\hline Lower secondary & 0.09 & 0.09 & 0.00 & 0.02 & 0.13 & 0.09 & $-0.04 * *$ & 0.02 \\
\hline Upper secondary & 0.54 & 0.56 & 0.02 & 0.03 & 0.59 & 0.56 & -0.03 & 0.03 \\
\hline Tertiary & 0.37 & 0.35 & -0.02 & 0.03 & 0.28 & 0.34 & $0.07 * *$ & 0.03 \\
\hline Father"s education & & & & & & & & \\
\hline Lower secondary & 0.06 & 0.06 & 0.00 & 0.01 & 0.09 & 0.07 & -0.02 & 0.02 \\
\hline Upper secondary & 0.47 & 0.46 & -0.01 & 0.03 & 0.51 & 0.48 & -0.03 & 0.03 \\
\hline Tertiary & 0.45 & 0.46 & 0.02 & 0.03 & 0.37 & 0.41 & 0.05 & 0.03 \\
\hline Educ. father: miss. & 0.02 & 0.02 & 0.00 & 0.01 & 0.03 & 0.04 & 0.01 & 0.01 \\
\hline Migration family type 1 & 0.09 & 0.07 & -0.02 & 0.02 & 0.06 & 0.06 & 0.00 & 0.01 \\
\hline Migration family type 2 & 0.85 & 0.86 & 0.01 & 0.02 & 0.90 & 0.91 & 0.01 & 0.02 \\
\hline School programme: & & & & & & & & \\
\hline Vocational (low track) & 0.05 & 0.07 & 0.02 & 0.02 & 0.05 & 0.07 & 0.02 & 0.02 \\
\hline Apprenticeship & 0.26 & 0.23 & -0.04 & 0.0 & 0.26 & 0.24 & -0.02 & 0.03 \\
\hline$B M S$ & 0.13 & 0.16 & $0.03 *$ & 0.0 & 0.20 & 0.17 & -0.03 & 0.02 \\
\hline BHS & 0.33 & 0.30 & -0.03 & 0.0 & 0.31 & 0.32 & 0.01 & 0.03 \\
\hline AHS & 0.23 & 0.24 & 0.01 & 0.02 & 0.18 & 0.21 & 0.03 & 0.02 \\
\hline Number of observations & 716 & 764 & & & 680 & 680 & & \\
\hline
\end{tabular}

Notes: Estimations weighted by individual inverse probability weights provided in the PISA data set. The standard deviations refer to the 2006 data using the pooled sample from May to August. Significance levels are denoted by: $* * \mathrm{p}<0.05,{ }^{*} \mathrm{p}<0.1$. "Migration family type 1 " indicates families speaking the test language at home and in which at least one of the parents is foreign-born. "Migration family type 2" indicates families speaking the test language at home and where both parents are native-born. The base category are non-German speaking families. 
Table 2: Simple OLS regressions on test score differences between children born in June versus July 1990

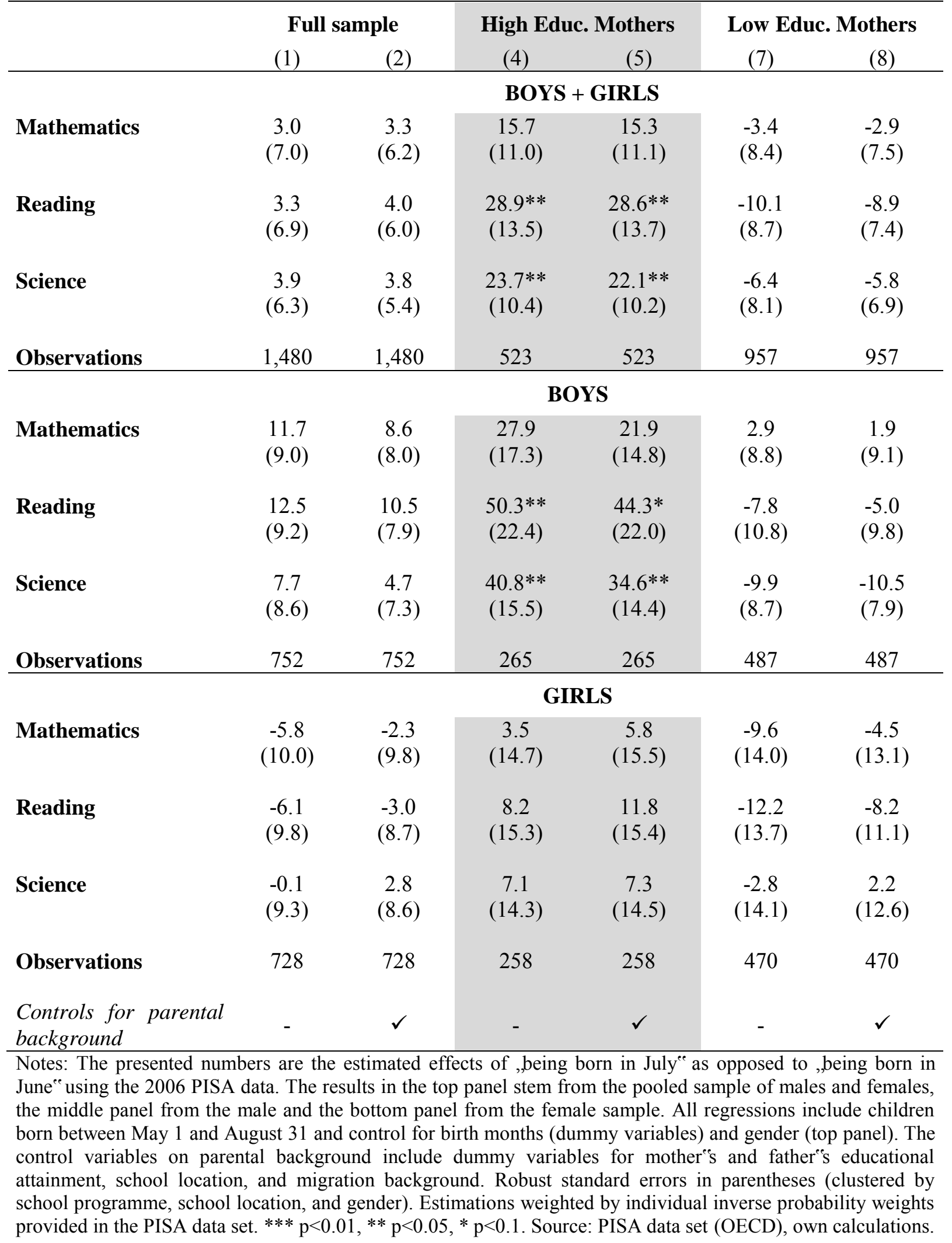


Table 3: RD-DID estimation results (boys and girls)

\begin{tabular}{|c|c|c|c|c|c|c|}
\hline & \multicolumn{2}{|c|}{ Full sample } & \multicolumn{2}{|c|}{ High Educ. Mothers } & \multicolumn{2}{|c|}{ Low Educ. Mothers } \\
\hline & (1) & (2) & (3) & (4) & $(5)$ & (6) \\
\hline \multicolumn{7}{|l|}{ Mathematics } \\
\hline Treatment effect & $\begin{array}{l}-0.4 \\
(6.9)\end{array}$ & $\begin{array}{c}2.0 \\
(6.7)\end{array}$ & $\begin{array}{l}17.2^{*} \\
(9.7)\end{array}$ & $\begin{array}{c}16.1 * \\
(9.2)\end{array}$ & $\begin{array}{l}-7.1 \\
(9.6)\end{array}$ & $\begin{array}{l}-5.0 \\
(8.8)\end{array}$ \\
\hline Post June & $\begin{array}{c}0.2 \\
(7.0)\end{array}$ & $\begin{array}{l}-2.5 \\
(6.8)\end{array}$ & $\begin{array}{l}-21.7^{*} \\
(10.9)\end{array}$ & $\begin{array}{c}-19.5^{*} \\
(9.9)\end{array}$ & $\begin{array}{c}8.3 \\
(8.6)\end{array}$ & $\begin{array}{c}6.0 \\
(8.0)\end{array}$ \\
\hline Born May & $\begin{array}{l}-2.3 \\
(5.9)\end{array}$ & $\begin{array}{l}-4.2 \\
(5.6)\end{array}$ & $\begin{array}{l}-11.7 \\
(8.9)\end{array}$ & $\begin{array}{l}-14.1 \\
(8.6)\end{array}$ & $\begin{array}{c}1.0 \\
(6.0)\end{array}$ & $\begin{array}{c}0.2 \\
(5.7)\end{array}$ \\
\hline Born July & $\begin{array}{l}-3.8 \\
(5.2)\end{array}$ & $\begin{array}{l}-2.9 \\
(4.8)\end{array}$ & $\begin{array}{c}8.4 \\
(8.8)\end{array}$ & $\begin{array}{c}5.1 \\
(8.6)\end{array}$ & $\begin{array}{l}-10.0 \\
(6.7)\end{array}$ & $\begin{array}{l}-8.4 \\
(5.2)\end{array}$ \\
\hline BC 1990 & $\begin{array}{c}5.0 \\
(6.4)\end{array}$ & $\begin{array}{c}3.9 \\
(5.8)\end{array}$ & $\begin{array}{c}-6.7 \\
(10.4)\end{array}$ & $\begin{array}{l}-6.2 \\
(8.9)\end{array}$ & $\begin{array}{c}8.1 \\
(6.8)\end{array}$ & $\begin{array}{c}8.3 \\
(6.4)\end{array}$ \\
\hline Constant & $\begin{array}{c}503.8^{* * *} \\
(12.4) \\
\end{array}$ & $\begin{array}{c}418.5^{* * *} \\
(19.0) \\
\end{array}$ & $\begin{array}{c}528.2 * * * \\
(14.2)\end{array}$ & $\begin{array}{c}457.1^{* * *} \\
(23.3)\end{array}$ & $\begin{array}{c}494.8^{* * *} \\
(12.4) \\
\end{array}$ & $\begin{array}{c}407.6^{* * * *} \\
(20.8) \\
\end{array}$ \\
\hline \multicolumn{7}{|l|}{ Reading } \\
\hline Treatment effect & $\begin{array}{l}-7.4 \\
(8.6)\end{array}$ & $\begin{array}{l}-4.1 \\
(8.1)\end{array}$ & $\begin{array}{l}22.7^{*} \\
(12.4)\end{array}$ & $\begin{array}{l}21.2^{*} \\
(11.7)\end{array}$ & $\begin{array}{l}-19.8^{*} \\
(10.4)\end{array}$ & $\begin{array}{c}-17.1^{*} \\
(9.5)\end{array}$ \\
\hline Post June & $\begin{array}{c}4.6 \\
(7.6)\end{array}$ & $\begin{array}{l}1.3 \\
(7.3)\end{array}$ & $\begin{array}{l}-24.6^{*} \\
(12.4)\end{array}$ & $\begin{array}{c}-22.4^{* *} \\
(11.1)\end{array}$ & $\begin{array}{l}15.4 * \\
(7.9)\end{array}$ & $\begin{array}{l}13.5^{*} \\
(7.5)\end{array}$ \\
\hline Born May & $\begin{array}{c}6.9 \\
(4.9)\end{array}$ & $\begin{array}{c}4.7 \\
(4.7)\end{array}$ & $\begin{array}{c}0.6 \\
(10.1)\end{array}$ & $\begin{array}{l}-2.7 \\
(8.9)\end{array}$ & $\begin{array}{c}8.4 \\
(5.7)\end{array}$ & $\begin{array}{c}8.2 \\
(5.8)\end{array}$ \\
\hline Born July & $\begin{array}{l}-1.8 \\
(5.7)\end{array}$ & $\begin{array}{l}-0.9 \\
(5.3)\end{array}$ & $\begin{array}{c}17.0 \\
(10.2)\end{array}$ & $\begin{array}{c}13.3 \\
(10.0)\end{array}$ & $\begin{array}{l}-11.3 \\
(7.9)\end{array}$ & $\begin{array}{l}-9.9 \\
(6.0)\end{array}$ \\
\hline BC1990 & $\begin{array}{c}6.5 \\
(7.0)\end{array}$ & $\begin{array}{c}4.8 \\
(6.4)\end{array}$ & $\begin{array}{l}-13.5 \\
(11.8)\end{array}$ & $\begin{array}{l}-12.2 \\
(11.2)\end{array}$ & $\begin{array}{c}13.0^{*} \\
(7.5)\end{array}$ & $\begin{array}{l}12.8^{*} \\
(7.1)\end{array}$ \\
\hline Constant & $\begin{array}{c}515.9^{* * *} \\
(13.0) \\
\end{array}$ & $\begin{array}{c}408.7 * * * \\
(22.2) \\
\end{array}$ & $\begin{array}{c}545.7 * * * \\
(15.7) \\
\end{array}$ & $\begin{array}{c}447.5^{* * * *} \\
(27.5) \\
\end{array}$ & $\begin{array}{c}505.3^{* * * *} \\
(13.6) \\
\end{array}$ & $\begin{array}{c}399.3^{* * *} \\
(24.8) \\
\end{array}$ \\
\hline \multicolumn{7}{|l|}{ Science } \\
\hline Treatment effect & $\begin{array}{l}-1.0 \\
(7.6)\end{array}$ & $\begin{array}{c}2.1 \\
(7.4)\end{array}$ & $\begin{array}{c}23.7 * * \\
(10.3)\end{array}$ & $\begin{array}{c}23.0^{* *} \\
(10.0)\end{array}$ & $\begin{array}{l}-11.1 \\
(9.9)\end{array}$ & $\begin{array}{l}-8.5 \\
(9.0)\end{array}$ \\
\hline Post June & $\begin{array}{c}0.7 \\
(7.0)\end{array}$ & $\begin{array}{l}-2.7 \\
(6.8)\end{array}$ & $\begin{array}{c}-22.0^{* *} \\
(10.6)\end{array}$ & $\begin{array}{c}-20.7^{* *} \\
(9.7)\end{array}$ & $\begin{array}{c}9.0 \\
(8.6)\end{array}$ & $\begin{array}{c}6.4 \\
(8.0)\end{array}$ \\
\hline Born May & $\begin{array}{c}3.9 \\
(5.9)\end{array}$ & $\begin{array}{c}1.6 \\
(5.7)\end{array}$ & $\begin{array}{c}0.5 \\
(7.8)\end{array}$ & $\begin{array}{l}-2.7 \\
(6.9)\end{array}$ & $\begin{array}{c}4.2 \\
(6.9)\end{array}$ & $\begin{array}{c}3.4 \\
(6.8)\end{array}$ \\
\hline Born July & $\begin{array}{l}-1.1 \\
(5.3)\end{array}$ & $\begin{array}{l}-0.1 \\
(5.0)\end{array}$ & $\begin{array}{l}13.1 \\
(8.7)\end{array}$ & $\begin{array}{c}9.6 \\
(8.7)\end{array}$ & $\begin{array}{l}-8.2 \\
(7.5)\end{array}$ & $\begin{array}{l}-6.6 \\
(5.8)\end{array}$ \\
\hline BC1990 & $\begin{array}{c}22.1 * * * \\
(6.8)\end{array}$ & $\begin{array}{c}20.5^{* * *} \\
(6.2)\end{array}$ & $\begin{array}{c}5.2 \\
(10.2)\end{array}$ & $\begin{array}{c}5.4 \\
(8.8)\end{array}$ & $\begin{array}{c}27.6^{* * *} \\
(7.3)\end{array}$ & $\begin{array}{c}27.2 * * * \\
(6.9)\end{array}$ \\
\hline Constant & $\begin{array}{c}495.0^{* * *} \\
(12.7)\end{array}$ & $\begin{array}{c}388.4^{* * *} \\
(18.1)\end{array}$ & $\begin{array}{c}520.5^{* * *} \\
(14.6)\end{array}$ & $\begin{array}{c}419.7^{* * *} \\
(24.0)\end{array}$ & $\begin{array}{c}485.9^{* * *} \\
(12.9)\end{array}$ & $\begin{array}{c}380.3 * * * \\
(18.7)\end{array}$ \\
\hline Observations & 2,840 & 2,840 & 943 & 943 & 1,897 & 1,897 \\
\hline Background controls & - & $\checkmark$ & - & $\checkmark$ & - & $\checkmark$ \\
\hline
\end{tabular}


Table 4: RD-DID estimation results by gender.

\begin{tabular}{|c|c|c|c|c|c|c|}
\hline & (1) & (2) & (3) & (4) & (5) & (6) \\
\hline & \multicolumn{2}{|c|}{ Full sample } & \multicolumn{2}{|c|}{ High Educ. Mothers } & \multicolumn{2}{|c|}{ Low Educ. Mothers } \\
\hline \multirow[b]{2}{*}{ Mathematics } & & & \multicolumn{2}{|c|}{ BOYS } & & \\
\hline & $\begin{array}{c}0.1 \\
(7.9)\end{array}$ & $\begin{array}{c}0.3 \\
(8.1)\end{array}$ & $\begin{array}{c}17.9 \\
(12.4)\end{array}$ & $\begin{array}{c}15.8 \\
(12.3)\end{array}$ & $\begin{array}{c}-8.4 \\
(13.2)\end{array}$ & $\begin{array}{c}-9.0 \\
(11.8)\end{array}$ \\
\hline Reading & $\begin{array}{l}-7.3 \\
(9.8)\end{array}$ & $\begin{array}{l}-6.8 \\
(9.7)\end{array}$ & $\begin{array}{c}34.0^{* *} \\
(15.2)\end{array}$ & $\begin{array}{l}33.1^{* *} \\
(15.0)\end{array}$ & $\begin{array}{l}-27.7^{*} \\
(14.5)\end{array}$ & $\begin{array}{c}-26.6 * * \\
(12.9)\end{array}$ \\
\hline Science & $\begin{array}{l}-2.1 \\
(9.2)\end{array}$ & $\begin{array}{l}-1.2 \\
(9.2)\end{array}$ & $\begin{array}{c}41.0^{* * *} \\
(10.9)\end{array}$ & $\begin{array}{c}40.4^{* * *} \\
(11.4)\end{array}$ & $\begin{array}{l}-23.7 \\
(15.4)\end{array}$ & $\begin{array}{l}-23.3^{*} \\
(13.4)\end{array}$ \\
\hline \multirow[t]{2}{*}{ Observations } & 1,426 & 1,426 & 482 & 482 & 944 & 944 \\
\hline & & & \multicolumn{2}{|c|}{ GIRLS } & & \\
\hline Mathematics & $\begin{array}{c}-0.5 \\
(11.1)\end{array}$ & $\begin{array}{c}4.1 \\
(10.7)\end{array}$ & $\begin{array}{c}18.2 \\
(15.5)\end{array}$ & $\begin{array}{c}16.0 \\
(15.2)\end{array}$ & $\begin{array}{c}-5.6 \\
(14.3)\end{array}$ & $\begin{array}{c}-2.0 \\
(13.3)\end{array}$ \\
\hline Reading & $\begin{array}{c}-7.4 \\
(13.7)\end{array}$ & $\begin{array}{c}-1.9 \\
(12.6)\end{array}$ & $\begin{array}{c}13.4 \\
(19.7)\end{array}$ & $\begin{array}{c}13.9 \\
(19.1)\end{array}$ & $\begin{array}{l}-12.8 \\
(15.5)\end{array}$ & $\begin{array}{c}-8.9 \\
(14.0)\end{array}$ \\
\hline Science & $\begin{array}{c}0.6 \\
(12.1)\end{array}$ & $\begin{array}{c}5.8 \\
(11.9)\end{array}$ & $\begin{array}{c}7.8 \\
(16.7)\end{array}$ & $\begin{array}{c}6.3 \\
(15.8)\end{array}$ & $\begin{array}{c}1.7 \\
(14.1)\end{array}$ & $\begin{array}{c}5.8 \\
(13.1)\end{array}$ \\
\hline Observations & 1,414 & 1,414 & 461 & 461 & 953 & 953 \\
\hline $\begin{array}{l}\text { Background } \\
\text { controls }\end{array}$ & - & $\checkmark$ & - & $\checkmark$ & - & $\checkmark$ \\
\hline \multicolumn{7}{|c|}{$\begin{array}{l}\text { Notes: Each cell reports the estimated treatment effect from a separate regression. The upper panel includes only } \\
\text { male, the lower panel only female students. All regressions include dummy variable controls for survey year, } \\
\text { birth months and for all children born post June. The control variables on parental background include dummy } \\
\text { variables for mother's and fatheres educational attainment, school location, and migration background. Robust } \\
\text { standard errors in parentheses (clustered by school programme, school location, and gender). Estimations } \\
\text { weighted by individual inverse probability weights provided in the PISA data set. *** p }<0.01, * * p<0.05 \text {, * } \\
\text { p }<0.1 \text {. Source: PISA data set (OECD), own calculations. }\end{array}$} \\
\hline
\end{tabular}


Table 5: RD-DID estimates based on symmetrically extended estimation samples (up to four pre- and post-reform birth months)

\begin{tabular}{|c|c|c|c|c|c|c|}
\hline & \multicolumn{3}{|c|}{ High Educ. Mothers } & \multicolumn{3}{|c|}{ Low Educ. Mothers } \\
\hline & $\begin{array}{c}(1) \\
\text { Mar-Oct }\end{array}$ & $\begin{array}{c}(2) \\
\text { Apr-Sep }\end{array}$ & $\begin{array}{c}\text { (3) } \\
\text { May-Aug }\end{array}$ & $\begin{array}{c}(4) \\
\text { Mar-Oct }\end{array}$ & $\begin{array}{c}5) \\
\text { Apr-Sep }\end{array}$ & $\begin{array}{c}\text { (6) } \\
\text { May-Aug }\end{array}$ \\
\hline & \multicolumn{3}{|c|}{ BOYS + GIRLS } & \multicolumn{3}{|c|}{ BOYS + GIRLS } \\
\hline Mathematics & $\begin{array}{c}5.7 \\
(7.7)\end{array}$ & $\begin{array}{c}9.9 \\
(7.3)\end{array}$ & $\begin{array}{l}16.4^{*} \\
(9.3)\end{array}$ & $\begin{array}{c}2.2 \\
(6.5)\end{array}$ & $\begin{array}{c}0.5 \\
(7.3)\end{array}$ & $\begin{array}{l}-5.6 \\
(9.1)\end{array}$ \\
\hline Reading & $\begin{array}{c}9.2 \\
(9.5)\end{array}$ & $\begin{array}{l}13.1 \\
(9.8)\end{array}$ & $\begin{array}{l}20.6^{*} \\
(11.7)\end{array}$ & $\begin{array}{l}-8.1 \\
(6.8)\end{array}$ & $\begin{array}{l}-9.7 \\
(7.7)\end{array}$ & $\begin{array}{c}-16.3^{*} \\
(9.2)\end{array}$ \\
\hline Science & $\begin{array}{l}11.7 \\
(8.7)\end{array}$ & $\begin{array}{l}15.9^{*} \\
(8.9)\end{array}$ & $\begin{array}{c}23.1^{* *} \\
(10.1)\end{array}$ & $\begin{array}{c}-3.1 \\
(7.1)\end{array}$ & $\begin{array}{l}-5.1 \\
(7.7)\end{array}$ & $\begin{array}{l}-8.8 \\
(9.1)\end{array}$ \\
\hline \multirow[t]{2}{*}{ Observations } & 1,887 & 1,425 & 943 & 3,772 & 2,840 & 1,897 \\
\hline & \multicolumn{3}{|c|}{ BOYS } & \multicolumn{3}{|c|}{ BOYS } \\
\hline Mathematics & $\begin{array}{c}13.3 \\
(11.2)\end{array}$ & $\begin{array}{l}13.5 \\
(9.7)\end{array}$ & $\begin{array}{c}15.8 \\
(12.3)\end{array}$ & $\begin{array}{l}-3.0 \\
(8.9)\end{array}$ & $\begin{array}{c}-3.6 \\
(10.3)\end{array}$ & $\begin{array}{c}-9.0 \\
(11.8)\end{array}$ \\
\hline Reading & $\begin{array}{c}27.2 * * \\
(11.6)\end{array}$ & $\begin{array}{c}28.9^{* *} \\
(12.0)\end{array}$ & $\begin{array}{c}33.1^{* *} \\
(15.0)\end{array}$ & $\begin{array}{l}-16.8 \\
(10.1)\end{array}$ & $\begin{array}{l}-20.9^{*} \\
(12.2)\end{array}$ & $\begin{array}{c}-26.6^{* *} \\
(12.9)\end{array}$ \\
\hline Science & $\begin{array}{c}32.6^{* * *} \\
(10.4)\end{array}$ & $\begin{array}{c}34.4 * * * \\
(9.9)\end{array}$ & $\begin{array}{c}40.4^{* * *} \\
(11.4)\end{array}$ & $\begin{array}{c}-16.9 * \\
(9.7)\end{array}$ & $\begin{array}{l}-19.0 \\
(11.1)\end{array}$ & $\begin{array}{l}-23.3^{*} \\
(13.4)\end{array}$ \\
\hline \multirow[t]{2}{*}{ Observations } & 953 & 716 & 482 & 1,866 & 1,397 & 944 \\
\hline & \multicolumn{3}{|c|}{ GIRLS } & \multicolumn{3}{|c|}{ GIRLS } \\
\hline Mathematics & $\begin{array}{c}-0.2 \\
(10.6)\end{array}$ & $\begin{array}{c}6.0 \\
(11.0)\end{array}$ & $\begin{array}{c}16.0 \\
(15.2)\end{array}$ & $\begin{array}{c}7.3 \\
(9.0)\end{array}$ & $\begin{array}{c}4.9 \\
(10.0)\end{array}$ & $\begin{array}{c}-2.0 \\
(13.3)\end{array}$ \\
\hline Reading & $\begin{array}{c}-9.7 \\
(14.5)\end{array}$ & $\begin{array}{c}-1.3 \\
(14.6)\end{array}$ & $\begin{array}{c}13.9 \\
(19.1)\end{array}$ & $\begin{array}{c}4.0 \\
(9.1)\end{array}$ & $\begin{array}{c}2.3 \\
(9.9)\end{array}$ & $\begin{array}{c}-8.9 \\
(14.0)\end{array}$ \\
\hline Science & $\begin{array}{c}-8.2 \\
(11.6)\end{array}$ & $\begin{array}{c}-2.6 \\
(12.6)\end{array}$ & $\begin{array}{c}6.3 \\
(15.8)\end{array}$ & $\begin{array}{c}11.6 \\
(10.1)\end{array}$ & $\begin{array}{c}9.3 \\
(11.1)\end{array}$ & $\begin{array}{c}5.8 \\
(13.1)\end{array}$ \\
\hline Observations & 934 & 709 & 461 & 1,906 & 1,443 & 953 \\
\hline
\end{tabular}

Notes: Each cell reports the estimated treatment effect from a separate regression. All regressions include dummy variables for month of birth, a year dummy for 2006, a dummy variable for all children born after June. Estimations from columns 1, 2, 4, and 5 include a further dummy variable for all children born between September and December to account for the school entry cut-off date in Austria and an interaction effect of this dummy variable with the year 2006 variable to account for potential general trends in school entry or repetition norms. The control variables on parental background include dummy variables for father"s educational attainment, school location, and migration background of the family. Robust standard errors in parentheses (clustered by school programme, school location, and gender). Estimations weighted by individual inverse probability weights provided in the PISA data set. ${ }^{* * *} \mathrm{p}<0.01,{ }^{* *} \mathrm{p}<0.05,{ }^{*} \mathrm{p}<0.1$. Source: PISA data set (OECD), own calculations. 
Table 6: RD-DDD estimations including German students as further control group

\begin{tabular}{|c|c|c|c|c|c|c|}
\hline & \multicolumn{3}{|c|}{ High Educ. Mothers } & \multicolumn{3}{|c|}{ Low Educ. Mothers } \\
\hline & $\begin{array}{c}(1) \\
\text { Mar-Oct }\end{array}$ & $\begin{array}{c}(2) \\
\text { Apr-Sep }\end{array}$ & $\begin{array}{c}\text { (3) } \\
\text { May-Aug }\end{array}$ & $\begin{array}{c}(4) \\
\text { Mar-Oct }\end{array}$ & $\begin{array}{c}5) \\
\text { Apr-Sep } \\
\end{array}$ & $\begin{array}{c}\text { (6) } \\
\text { May-Aug }\end{array}$ \\
\hline & \multicolumn{3}{|c|}{ BOYS + GIRLS } & \multicolumn{3}{|c|}{ BOYS + GIRLS } \\
\hline Mathematics & $\begin{array}{l}19.2 * \\
(9.9)\end{array}$ & $\begin{array}{l}22.2^{*} \\
(11.3)\end{array}$ & $\begin{array}{c}22.8 \\
(14.8)\end{array}$ & $\begin{array}{c}-6.2 \\
(10.0)\end{array}$ & $\begin{array}{c}-9.9 \\
(11.7)\end{array}$ & $\begin{array}{l}-17.1 \\
(14.1)\end{array}$ \\
\hline Reading & $\begin{array}{c}18.6 \\
(13.5)\end{array}$ & $\begin{array}{c}20.6 \\
(15.2)\end{array}$ & $\begin{array}{c}25.1 \\
(17.3)\end{array}$ & $\begin{array}{l}-23.2 * \\
(12.3)\end{array}$ & $\begin{array}{l}-26.5^{*} \\
(13.4)\end{array}$ & $\begin{array}{l}-31.0^{*} \\
(15.5)\end{array}$ \\
\hline Science & $\begin{array}{c}29.1 * * \\
(11.8)\end{array}$ & $\begin{array}{c}33.5^{* *} \\
(13.3)\end{array}$ & $\begin{array}{c}37.8^{* *} \\
(15.3)\end{array}$ & $\begin{array}{l}-14.9 \\
(11.3)\end{array}$ & $\begin{array}{l}-17.0 \\
(13.1)\end{array}$ & $\begin{array}{l}-20.9 \\
(14.8)\end{array}$ \\
\hline \multirow[t]{2}{*}{ Observations } & 4,228 & 3,212 & 2,158 & 6,519 & 4,968 & 3,325 \\
\hline & \multicolumn{3}{|c|}{ BOYS } & \multicolumn{3}{|c|}{ BOYS } \\
\hline Mathematics & $\begin{array}{c}28.5^{* *} \\
(13.0)\end{array}$ & $\begin{array}{c}32.7 * * \\
(13.4)\end{array}$ & $\begin{array}{l}38.1^{* *} \\
(18.2)\end{array}$ & $\begin{array}{c}-33.1^{* *} \\
(15.8)\end{array}$ & $\begin{array}{l}-34.1 * \\
(17.2)\end{array}$ & $\begin{array}{c}-37.2 * * \\
(16.7)\end{array}$ \\
\hline Reading & $\begin{array}{l}32.2^{*} \\
(16.7)\end{array}$ & $\begin{array}{l}36.1^{*} \\
(18.3)\end{array}$ & $\begin{array}{l}40.0^{*} \\
(22.6)\end{array}$ & $\begin{array}{c}-55.2 * * * \\
(19.3)\end{array}$ & $\begin{array}{c}-56.8^{* *} \\
(21.2)\end{array}$ & $\begin{array}{c}-57.1 * * \\
(22.1)\end{array}$ \\
\hline Science & $\begin{array}{c}48.6^{* * *} \\
(10.6)\end{array}$ & $\begin{array}{c}56.6^{* * * *} \\
(12.1)\end{array}$ & $\begin{array}{c}66.9 * * * \\
(15.8)\end{array}$ & $\begin{array}{c}-51.5 * * * \\
(16.2)\end{array}$ & $\begin{array}{c}-53.2 * * * \\
(18.6)\end{array}$ & $\begin{array}{c}-53.1 * * * \\
(18.6)\end{array}$ \\
\hline \multirow[t]{2}{*}{ Observations } & 2,157 & 1,634 & 1,113 & 3,209 & 2,438 & 1,636 \\
\hline & \multicolumn{3}{|c|}{ GIRLS } & \multicolumn{3}{|c|}{ GIRLS } \\
\hline Mathematics & $\begin{array}{c}11.1 \\
(16.4)\end{array}$ & $\begin{array}{c}11.6 \\
(19.0)\end{array}$ & $\begin{array}{c}9.4 \\
(23.6)\end{array}$ & $\begin{array}{c}16.2 \\
(11.3)\end{array}$ & $\begin{array}{c}10.1 \\
(15.0)\end{array}$ & $\begin{array}{c}2.6 \\
(21.7)\end{array}$ \\
\hline Reading & $\begin{array}{c}0.9 \\
(18.4)\end{array}$ & $\begin{array}{c}3.2 \\
(21.2)\end{array}$ & $\begin{array}{c}13.6 \\
(21.2)\end{array}$ & $\begin{array}{c}7.9 \\
(12.6)\end{array}$ & $\begin{array}{c}1.6 \\
(16.2)\end{array}$ & $\begin{array}{c}-8.5 \\
(23.9)\end{array}$ \\
\hline Science & $\begin{array}{c}9.3 \\
(18.9)\end{array}$ & $\begin{array}{c}9.5 \\
(21.5)\end{array}$ & $\begin{array}{c}10.4 \\
(23.3)\end{array}$ & $\begin{array}{c}16.9 \\
(13.3)\end{array}$ & $\begin{array}{c}14.0 \\
(17.3)\end{array}$ & $\begin{array}{c}9.9 \\
(22.1)\end{array}$ \\
\hline Observations & 2,071 & 1,578 & 1,045 & 3,310 & 2,530 & 1,689 \\
\hline
\end{tabular}

Notes: Each cell reports the estimated treatment effect from a separate regression. All regressions include dummy variables for month of birth, year and country fixed effects, a dummy variable for all children born after June, interaction effects between year and the ,post June" dummy, year and country, country and ,post June". Estimations from columns 1, 2, 4, and 5 include a further dummy variable for all children born between September and December to account for the school entry cut-off date in Austria (and a year interaction). The control variables on parental background include dummy variables for father"s educational attainment, school location, and migration background of the family. Robust standard errors in parentheses (clustered by country, school track (more/less academic), school location, and gender). Estimations weighted by individual inverse probability weights provided in the PISA data set. ${ }^{* *} \mathrm{p}<0.01,{ }^{* *} \mathrm{p}<0.05,{ }^{*} \mathrm{p}<0.1$. Source: PISA data set (OECD), own calculations. 
Table 7: Robustness check. RD-DID estimations using only PISA 2006 data and Germany as a control group.

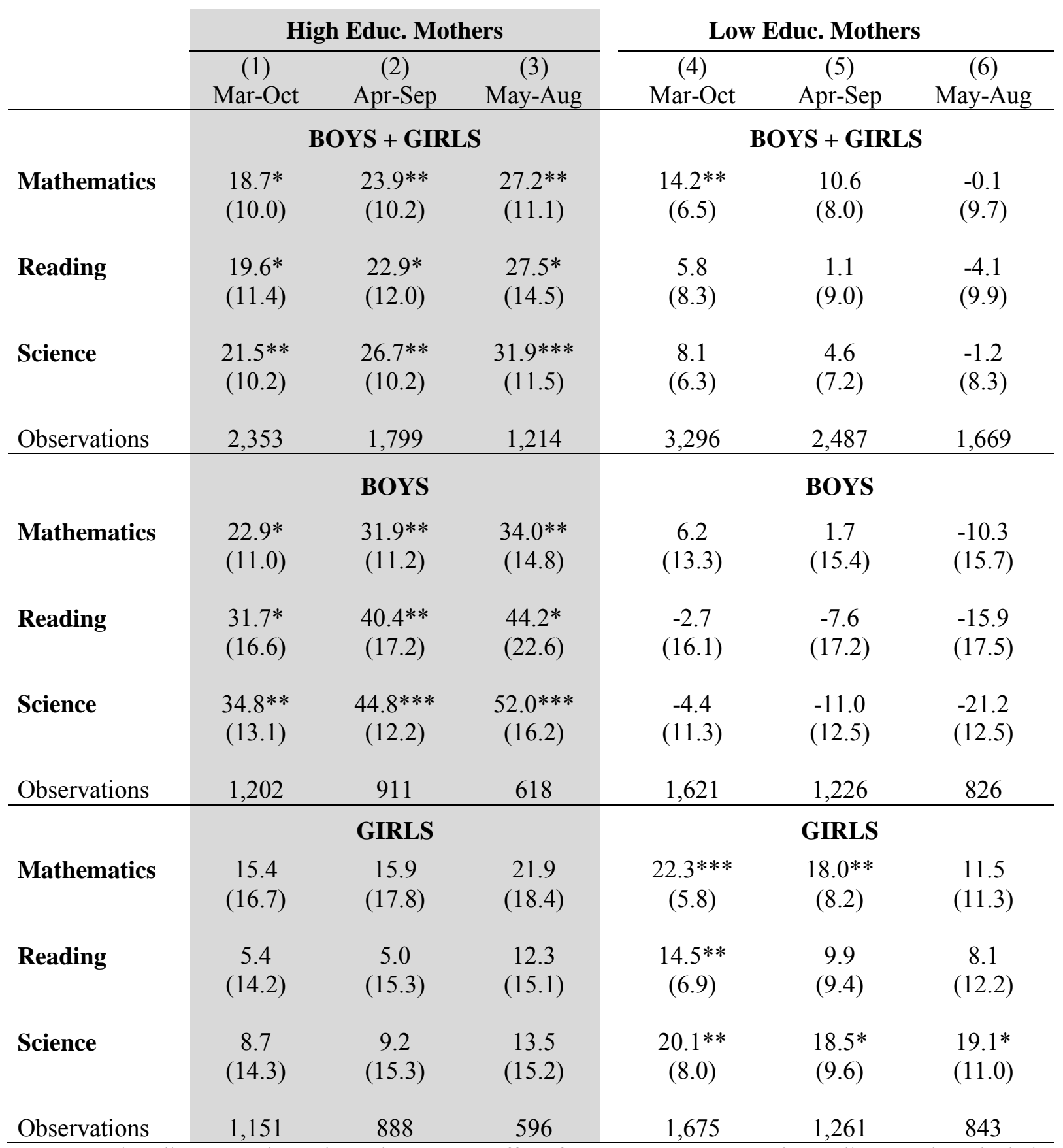

Notes: Each cell reports the estimated treatment effect from a separate regression. All regressions include dummy variables for month of birth, a dummy variable for all children born after June. Estimations from columns (1)-(4) include a further dummy variable for all children born between September and December to account for the school entry cut-off date in Austria. The control variables on parental background include dummy variables for father"s educational attainment, school location, and migration background of the family. Robust standard errors in parentheses (clustered by country, school programme, school location, and gender). Estimations weighted by individual inverse probability weights provided in the PISA data set. $* * * \mathrm{p}<0.01, * *$ $\mathrm{p}<0.05, * \mathrm{p}<0.1$. Source: PISA data set (OECD), own calculations. 
Table 8: RD-DID placebo tests

\begin{tabular}{|c|c|c|c|c|c|c|}
\hline & \multicolumn{3}{|c|}{$\begin{array}{c}\text { (A) } \\
\text { Pseudo cut-off is May } 1,1990 \\
\text { RD-DID 2006+2003 }\end{array}$} & \multicolumn{3}{|c|}{$\begin{array}{c}\text { (B) } \\
\begin{array}{c}\text { Pseudo cut-off is } \mathrm{Sep} 1,1990 \\
\text { RD-DID 2006+2003 }\end{array} \\
\end{array}$} \\
\hline & $\begin{array}{c}\text { Full } \\
\text { sample }\end{array}$ & $\begin{array}{l}\text { High Educ. } \\
\text { Mothers }\end{array}$ & $\begin{array}{c}\text { Low Educ. } \\
\text { mothers }\end{array}$ & $\begin{array}{l}\text { Full sample } \\
\text { sump }\end{array}$ & $\begin{array}{l}\text { High Educ. } \\
\text { Mothers }\end{array}$ & $\begin{array}{c}\text { Low Educ. } \\
\text { mothers }\end{array}$ \\
\hline & $\begin{array}{c}\text { (1) } \\
\text { Mar-Jun }\end{array}$ & $\begin{array}{c}(2) \\
\text { Mar-Jun } \\
\end{array}$ & $\begin{array}{c}(3) \\
\text { Mar-Jun }\end{array}$ & $\begin{array}{c}(4) \\
\text { Jul-Oct }\end{array}$ & $\begin{array}{c}\text { (5) } \\
\text { Jul-Oct }\end{array}$ & $\begin{array}{c}\text { (6) } \\
\text { Jul-Oct }\end{array}$ \\
\hline \multirow[b]{2}{*}{ Mathematics } & & BOYS & & & BOYS & \\
\hline & $\begin{array}{c}4.007 \\
(10.081)\end{array}$ & $\begin{array}{c}-5.903 \\
(14.688)\end{array}$ & $\begin{array}{c}10.418 \\
(12.885)\end{array}$ & $\begin{array}{l}-3.8 \\
(8.8)\end{array}$ & $\begin{array}{c}9.5 \\
(15.2)\end{array}$ & $\begin{array}{l}-10.5 \\
(10.9)\end{array}$ \\
\hline Reading & $\begin{array}{c}7.702 \\
(11.491)\end{array}$ & $\begin{array}{l}-14.833 \\
(17.469)\end{array}$ & $\begin{array}{c}19.133 \\
(14.598)\end{array}$ & $\begin{array}{l}-6.6 \\
(10.8)\end{array}$ & $\begin{array}{l}-0.8 \\
(14.7)\end{array}$ & $\begin{array}{l}-8.9 \\
(14.4)\end{array}$ \\
\hline Science & $\begin{array}{c}1.185 \\
(11.928)\end{array}$ & $\begin{array}{l}-15.328 \\
(13.059)\end{array}$ & $\begin{array}{c}10.248 \\
(15.292)\end{array}$ & $\begin{array}{l}-3.7 \\
(9.1)\end{array}$ & $\begin{array}{c}-2.8 \\
(15.6)\end{array}$ & $\begin{array}{c}-3.1 \\
(11.6)\end{array}$ \\
\hline Observations & 1,432 & 462 & 970 & 1,387 & 491 & 896 \\
\hline \multirow[b]{2}{*}{ Mathematics } & & GIRLS & & & GIRLS & \\
\hline & $\begin{array}{c}1.437 \\
(11.353)\end{array}$ & $\begin{array}{c}-26.332 \\
(15.491)\end{array}$ & $\begin{array}{c}18.209 \\
(16.229)\end{array}$ & $\begin{array}{c}-5.6 \\
(12.0)\end{array}$ & $\begin{array}{c}6.7 \\
(13.0)\end{array}$ & $\begin{array}{l}-10.4 \\
(16.1)\end{array}$ \\
\hline Reading & $\begin{array}{c}2.017 \\
(13.365)\end{array}$ & $\begin{array}{l}-39.974 * * \\
(15.263)\end{array}$ & $\begin{array}{c}25.166 \\
(19.199)\end{array}$ & $\begin{array}{c}-4.2 \\
(11.0)\end{array}$ & $\begin{array}{c}10.3 \\
(14.3)\end{array}$ & $\begin{array}{c}-9.9 \\
(12.3)\end{array}$ \\
\hline Science & $\begin{array}{l}-1.225 \\
(9.896)\end{array}$ & $\begin{array}{l}-23.605 \\
(13.953)\end{array}$ & $\begin{array}{c}12.143 \\
(12.958)\end{array}$ & $\begin{array}{c}1.4 \\
(11.3)\end{array}$ & $\begin{array}{l}23.8^{*} \\
(13.6)\end{array}$ & $\begin{array}{c}-8.6 \\
(13.4)\end{array}$ \\
\hline Observations & 1,361 & 450 & 911 & 1,479 & 484 & 995 \\
\hline
\end{tabular}

Notes: Each cell reports the estimated pseudo treatment effect from a separate regression. The left (right) three results are based on the sample of children born between April 1 and July 31 (July 1 and October 31) of 1987 and 1990. All regressions include a year dummy (bc1990) and control for mother"s and father"s educational attainment, school location, and migration background of the family. Furthermore the regressions include controls for birth months, a dummy variable for all children born after the pseudo cut-off dates May 1 (May and June) or September 1 (September and October) as well as year-pseudo reform interaction effect. Robust standard errors in parentheses (clustered by school programme, school location, and gender). Estimations weighted by individual inverse probability weights provided in the PISA data set. ${ }^{* *} \mathrm{p}<0.01,{ }^{* *} \mathrm{p}<0.05,{ }^{*} \mathrm{p}<0.1$. Source: PISA data set (OECD), own calculations. 
Table 9: Probability of being in lower than regular grade level (grade retention) or being enrolled in the academic track (linear probability models)

\begin{tabular}{|c|c|c|c|}
\hline & $\begin{array}{c}(1) \\
\text { Full sample }\end{array}$ & $\begin{array}{c}(2) \\
\text { High Educ. Mothers } \\
\end{array}$ & $\begin{array}{c}(3) \\
\text { Low Educ. Mothers } \\
\end{array}$ \\
\hline & \multicolumn{3}{|c|}{ BOYS + GIRLS } \\
\hline Retained & $\begin{array}{c}0.055 \\
(0.035)\end{array}$ & $\begin{array}{l}-0.022 \\
(0.059)\end{array}$ & $\begin{array}{c}0.089^{* *} \\
(0.041)\end{array}$ \\
\hline Academic track & $\begin{array}{l}-0.042 \\
(0.034)\end{array}$ & $\begin{array}{c}0.004 \\
(0.059)\end{array}$ & $\begin{array}{l}-0.067 \\
(0.043)\end{array}$ \\
\hline \multirow[t]{2}{*}{ Observations } & 2,840 & 943 & 1,897 \\
\hline & \multicolumn{2}{|r|}{ BOYS } & \multirow[b]{2}{*}{$\begin{array}{c}0.042 \\
(0.049)\end{array}$} \\
\hline Retained & $\begin{array}{c}0.019 \\
(0.051)\end{array}$ & $\begin{array}{l}-0.031 \\
(0.090)\end{array}$ & \\
\hline Academic track & $\begin{array}{l}-0.044 \\
(0.036)\end{array}$ & $\begin{array}{l}-0.005 \\
(0.062)\end{array}$ & $\begin{array}{l}-0.064 \\
(0.047)\end{array}$ \\
\hline \multirow[t]{2}{*}{ Observations } & 1,426 & 482 & 944 \\
\hline & & GIRLS & \multirow[b]{2}{*}{$\begin{array}{c}0.137 * * \\
(0.062)\end{array}$} \\
\hline Retained & $\begin{array}{c}0.089 * * \\
(0.040)\end{array}$ & $\begin{array}{c}0.002 \\
(0.077)\end{array}$ & \\
\hline Academic track & $\begin{array}{l}-0.047 \\
(0.057)\end{array}$ & $\begin{array}{c}0.019 \\
(0.091)\end{array}$ & $\begin{array}{l}-0.065 \\
(0.073)\end{array}$ \\
\hline Observations & 1,414 & 461 & 953 \\
\hline \multicolumn{4}{|c|}{$\begin{array}{l}\text { Notes: Each cell reports the estimated treatment effects from separate DID regressions controlling for the } \\
\text { standard set of background variables as in the original DID regressions in the main specification (e.g., Tables } 3 \\
\text { and 4). The samples consists of children born between May } 1 \text { and August } 31 \text { of } 1987 \text { or } 1990 \text {. The dependent } \\
\text { variables are two dummy variables indicating whether a student is enrolled in a lower than regular grade level } \\
\text { given his birth date and whether the student is enrolled in the academic track. Robust standard errors in } \\
\text { parentheses (clustered by school programme, school location, and gender). Estimations weighted by individual } \\
\text { inverse probability weights provided in the PISA data set. }{ }^{* *} p<0.01,{ }^{* *} p<0.05,{ }^{*} p<0.1 \text {. Source: PISA data set } \\
\text { (OECD), own calculations. }\end{array}$} \\
\hline
\end{tabular}


Figure 1: Local averages by subject and parametric fit (RD-DID graphs)
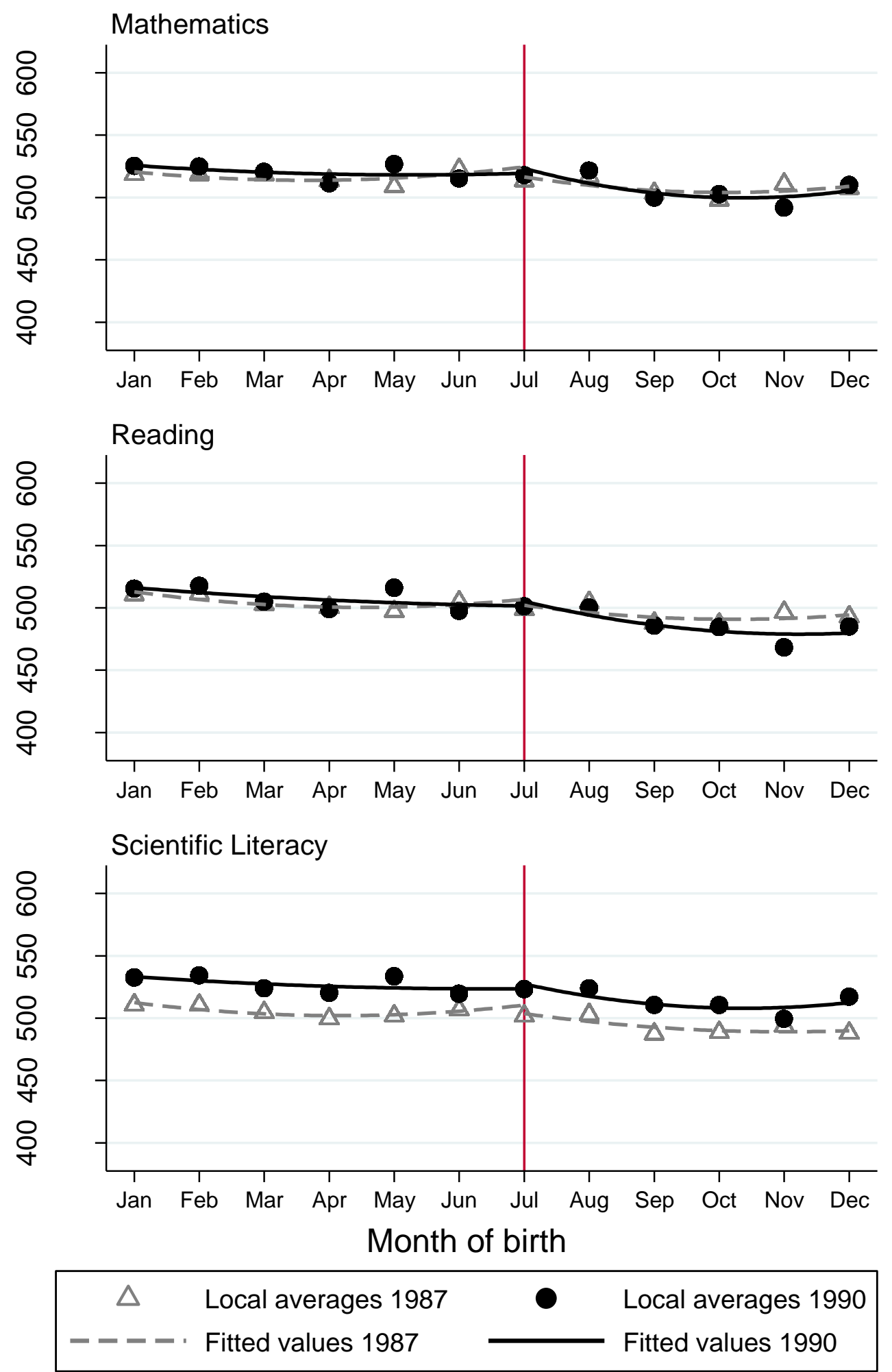

Notes: Average test scores by birth month plotted for the reform cohort 1990 and the control cohort 1987 (using official individual weights). The vertical line indicates the month of the parental leave reform (July 1, 1990). The curved line shows the predicted fit from two regressions of test scores on birth month and its square based on (1) all observations born between January and June and (2) born between July and December. 
Figure 2: Local averages and parametric fit for boys, by maternal LFP group (RD-DID graphs)
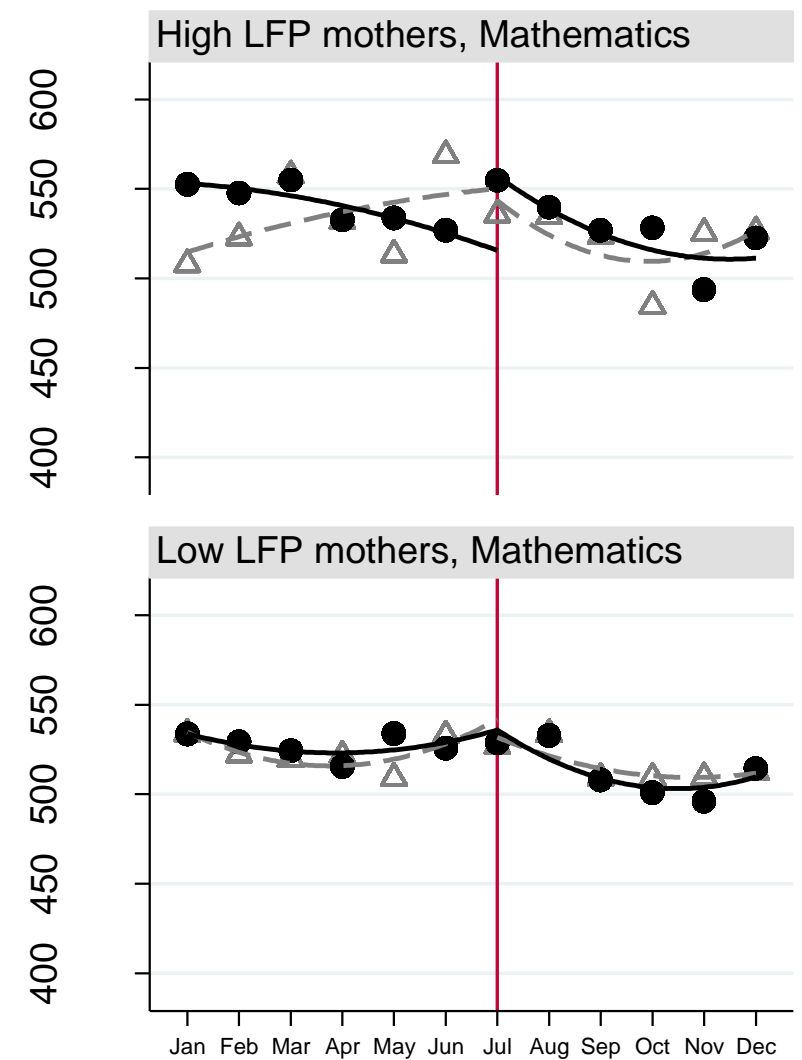

High LFP mothers, Reading

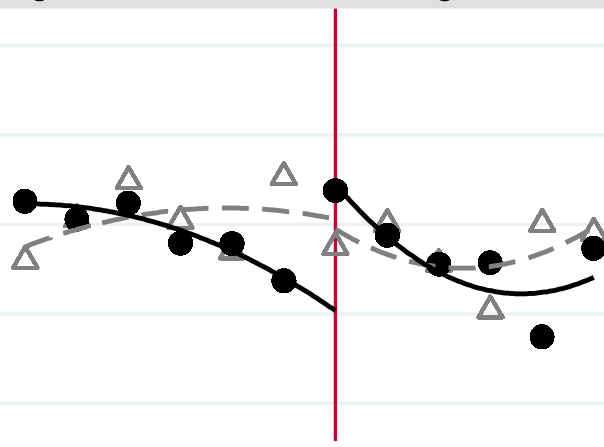

Low LFP mothers, Reading

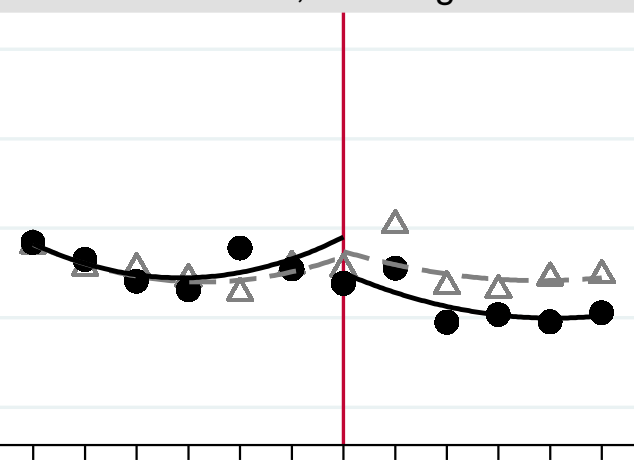

Jan Feb Mar Apr May Jun Jul Aug Sep Oct Nov Dec Month of birth
High LFP mothers, Scient. Literacy

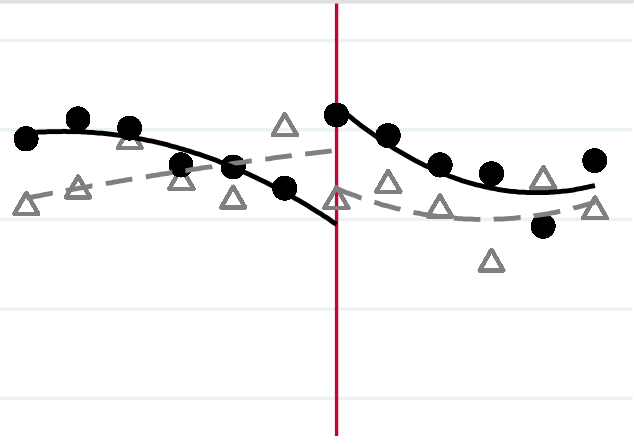

Low LFP mothers, Scient. Literacy

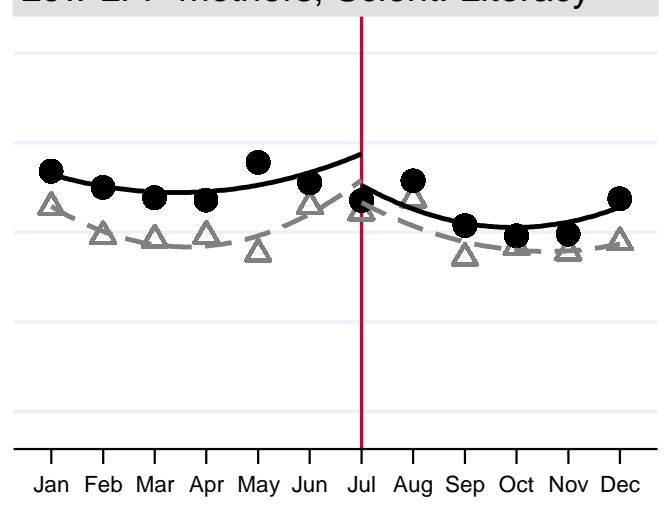

Fitted values 1990

Notes: Sample restricted to male students. Average test scores by birth month and mother"s LFP group plotted for the reform cohort 1990 and the control cohort 1987 (using official individual PISA weights). The vertical line indicates the month of the parental leave reform (July 1, 1990). The curved line shows the predicted fit from two regressions of test scores on birth month and its square based on (1) all observations born between January and June and (2) born between July and December. 
Figure 3: Local averages and parametric fit for girls, by maternal LFP group (RD-DID graphs)
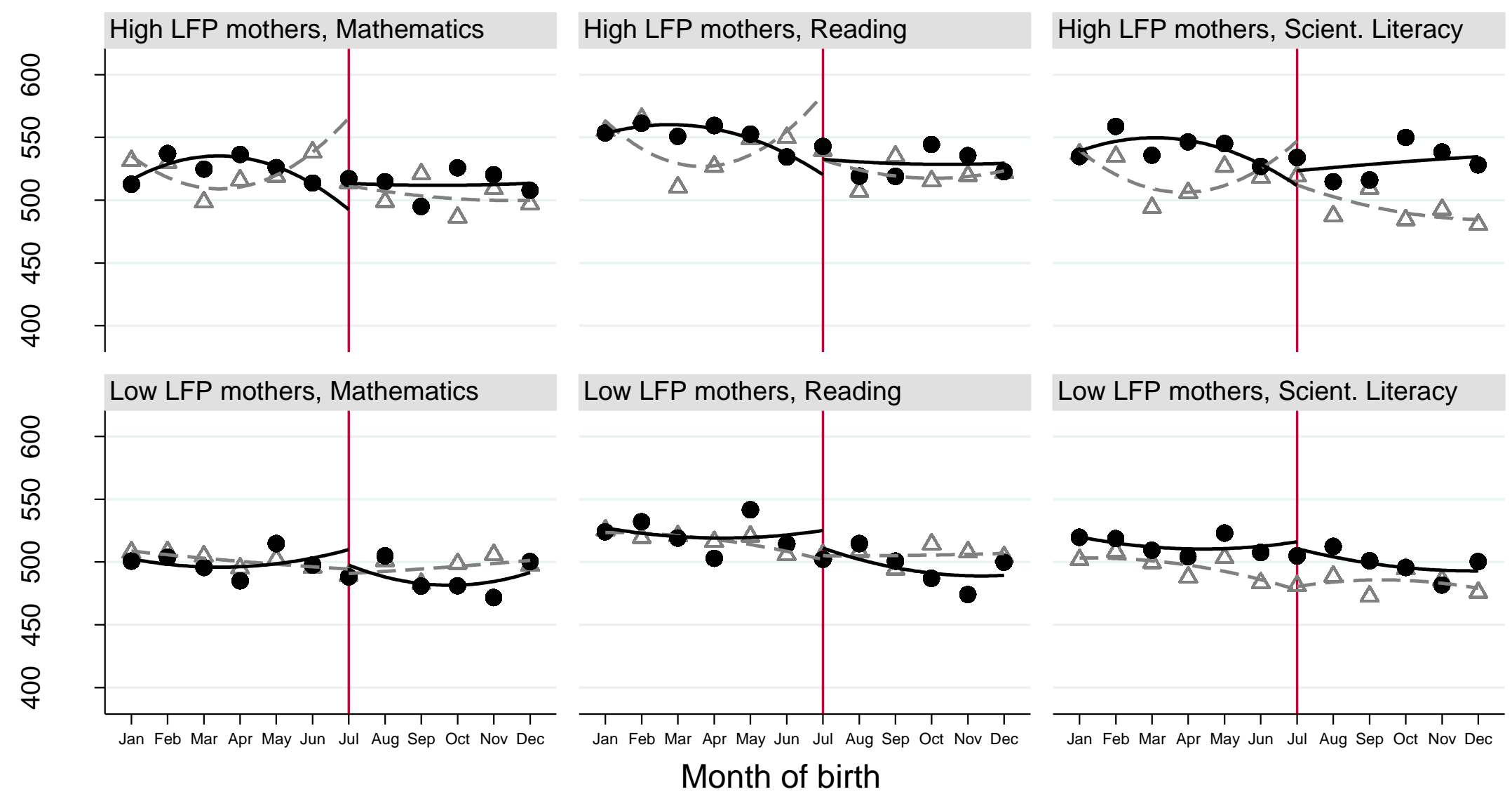

$\triangle$ Local averages $1987 \quad----=$ Fitted values 1987 Local averages 1990 Fitted values 1990

Notes: Sample restricted to female students. Average test scores by birth month and mother"s LFP group plotted for the reform cohort 1990 and the control cohort 1987 (using official individual PISA weights). The vertical line indicates the month of the parental leave reform (July 1, 1990). The curved line shows the predicted fit from two regressions of test scores on birth month and its square based on (1) all observations born between January and June and (2) born between July and December. 


\section{Online Appendix}

to the paper

\section{Parental Leave and Children"s Schooling Outcomes: \\ Quasi-Experimental Evidence from a Large Parental Leave Reform}

September 10, 2013

Natalia Danzer

Ifo Institute,

LMU University of Munich and IZA Bonn

danzer@ifo.de
Victor Lavy

Hebrew University, University of Warwick and NBER

msvictor@huji.ac.il 
Figure A 1: Share of pre- and post-reform mothers returning to work after birth

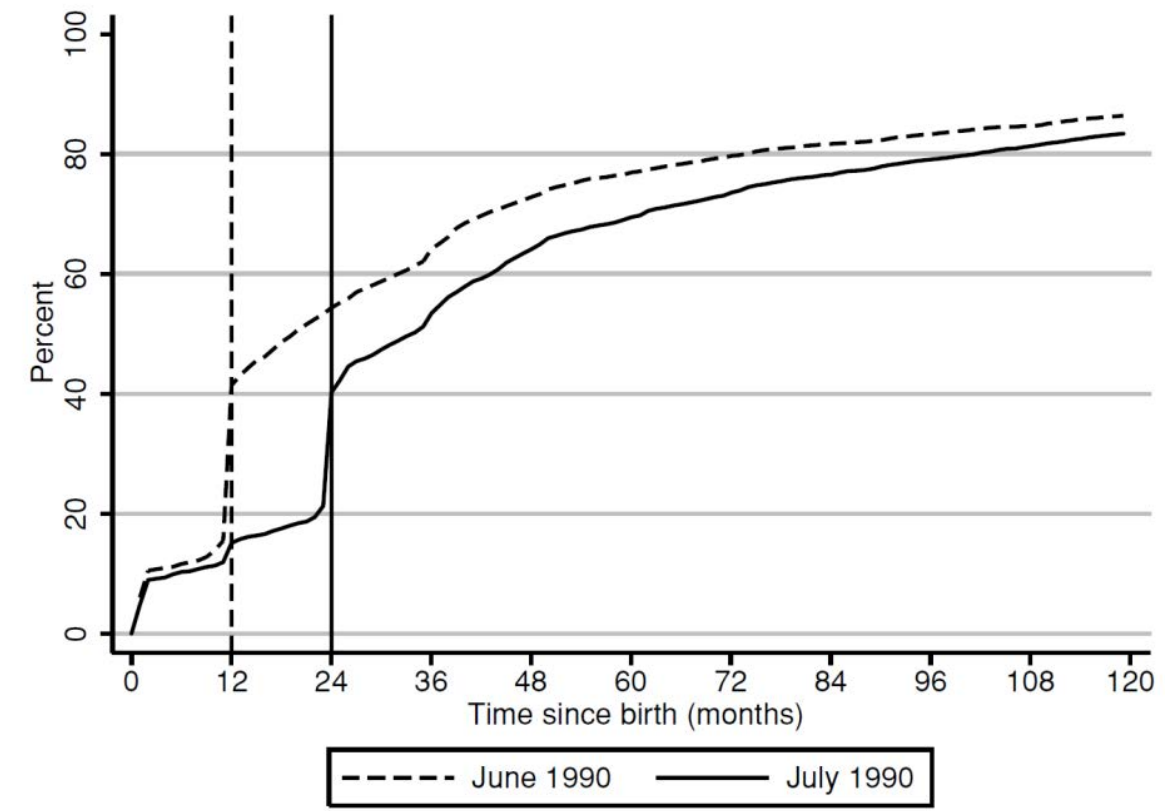

Source: Figure 5.B. taken from Lalive and Zweimüller (2009, p. 1387) [Lalive, Rafael and Josef Zweimüller. 2009. "How does Parental Leave Affect Fertility and Return to Work? Evidence from Two Natural Experiments." The Quarterly Journal of Economics, 124 (3): 1363-1402.] 
Figure A 2: Local averages and parametric fit, by student gender (RD-DD graphs)
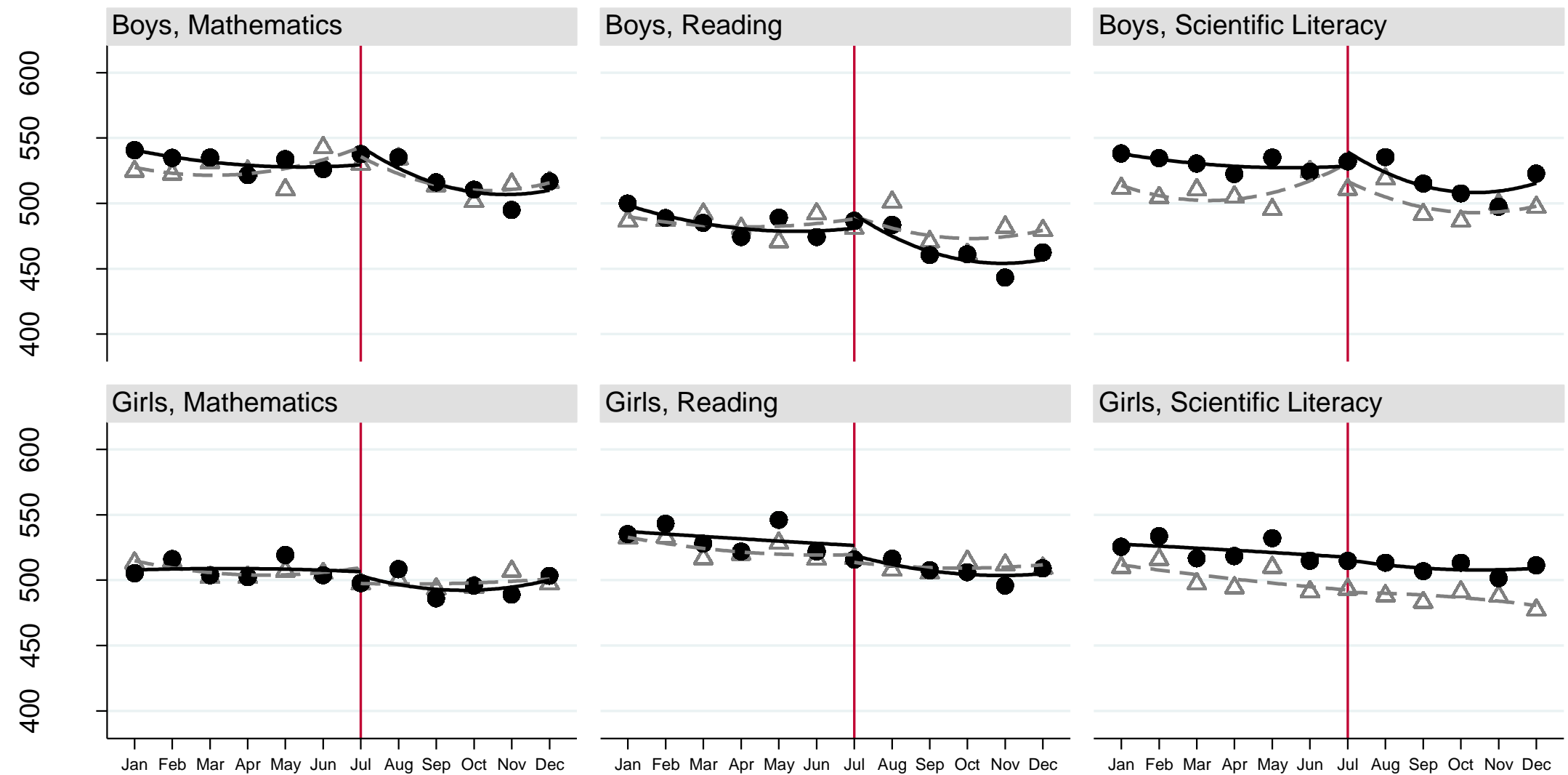

Month of birth

$\triangle$ Local averages $1987 \quad----$ Fitted values $1987 \quad$ Local averages $1990 \longrightarrow$ Fitted values 1990

Notes: Average test scores by birth month and student's gender plotted for the reform cohort 1990 and the control cohort 1987 (using official individual PISA weights). The vertical line indicates the month of the parental leave reform (July 1, 1990). The curved line shows the predicted fit from two regressions of test scores on birth month and its square based on (1) all observations born between January and June and (2) born between July and December. 
Figure A 3: Local averages and parametric fit, by maternal education (RD-DD graphs)

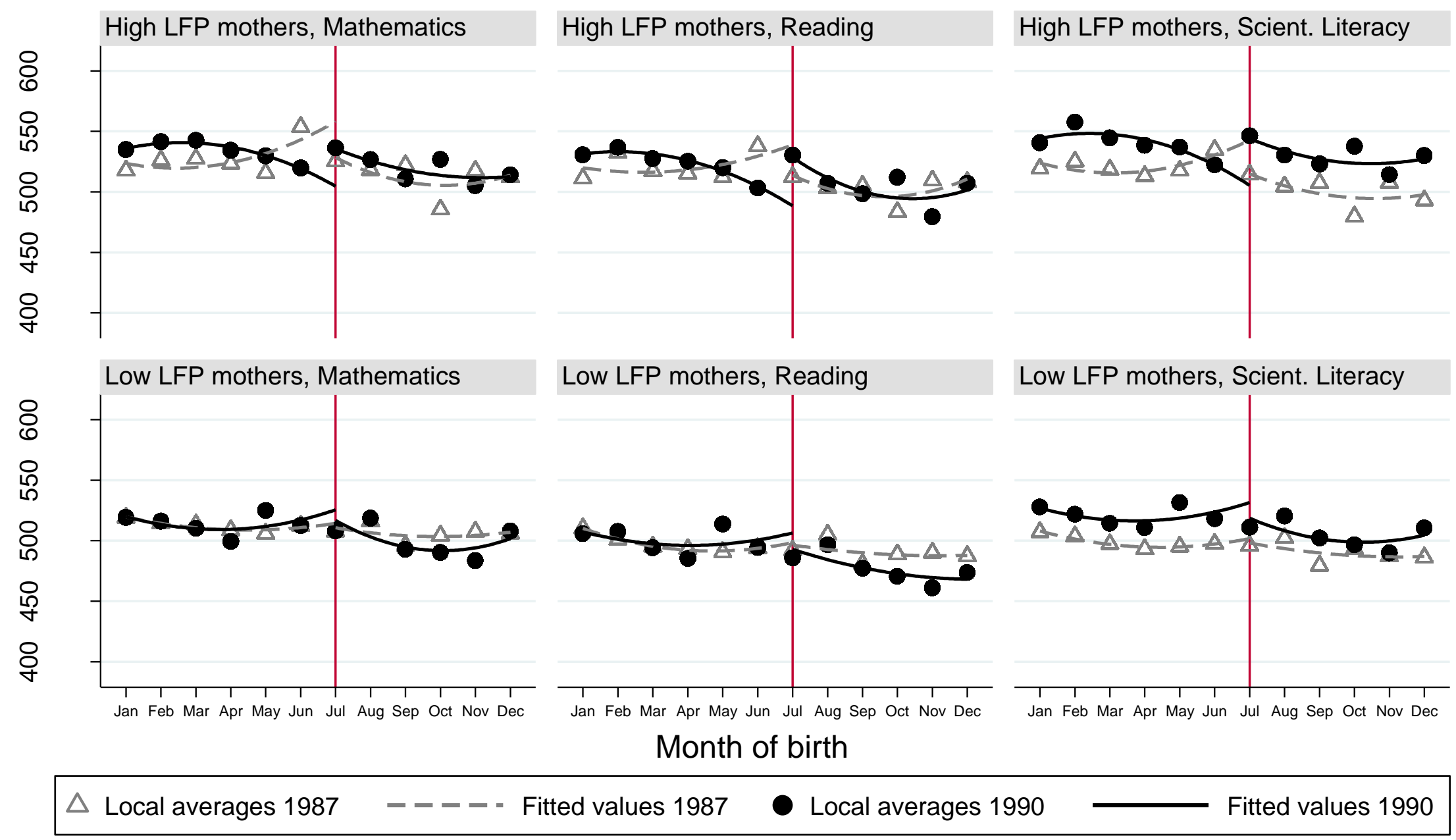


Table A 1: Overview of existing quasi-experimental studies using reforms in parental leave legislations to identify causal effects of maternal employment on child outcomes

\begin{tabular}{|c|c|c|c|c|c|c|c|}
\hline $\begin{array}{l}\text { Publication } \\
\text { (Authors } \\
\text { and Year) }\end{array}$ & $\begin{array}{l}\text { Country and } \\
\text { Data Source }\end{array}$ & $\begin{array}{l}\text { Year \& Substance of PL re- } \\
\text { form }\end{array}$ & $\begin{array}{l}\text { Assessed child out- } \\
\text { come(s) } \\
\text { (Short/Medium/Long run } \\
\text { effects) }\end{array}$ & $\begin{array}{l}\text { Main empirical } \\
\text { method }\end{array}$ & $\begin{array}{l}\text { Results on ef- } \\
\text { fect of reform } \\
\text { on child out- } \\
\text { comes }\end{array}$ & $\begin{array}{l}\text { Heterogenous ef- } \\
\text { fects }\end{array}$ & $\begin{array}{l}\text { Institutional back- } \\
\text { ground: provision of } \\
\text { child care }\end{array}$ \\
\hline $\begin{array}{l}\text { Baker and } \\
\text { Milligan } \\
(2010)\end{array}$ & $\begin{array}{l}\text { Canada: } \\
\text { National Longi- } \\
\text { tudinal Study } \\
\text { of Children and } \\
\text { Youth } \\
\text { (NLSCY); } \\
\text { about } 2,000 \\
\text { children per } \\
\text { cohort }\end{array}$ & $\begin{array}{l}\text { - December } 31,2000 \\
\text { - Max. duration of maternity } \\
\text { leave benefits raised from } 25 \text { to } \\
50 \text { weeks (out of which } 10 \text { and } \\
\text { respectively } 35 \text { weeks can be } \\
\text { claimed by mother or father) } \\
\text { - Pre-reform job protected ma- } \\
\text { ternity leave varied between } 18 \\
\text { and } 70 \text { weeks across regions. } \\
\text { Post-reform maternity leave } \\
\text { duration increased to at least } \\
52 \text { weeks in all regions. }\end{array}$ & $\begin{array}{l}\text { SR effects: } \\
\text { - Children between } 7 \text { and } \\
24 \text { months } \\
\text { - Parent-reported measures } \\
\text { of temperament, motor } \\
\text { and social development }\end{array}$ & $\begin{array}{l}\text { Test of differ- } \\
\text { ences between } \\
\text { average out- } \\
\text { comes of birth } \\
\text { cohorts born } \\
\text { before and after } \\
\text { the reform; } \\
\text { (regressions } \\
\text { based on six } \\
\text { yearly values) }\end{array}$ & $\begin{array}{l}\text { - Overall small } \\
\text { and mostly in- } \\
\text { significant ef- } \\
\text { fects on the } \\
\text { development } \\
\text { variables }\end{array}$ & - Not tested & $\begin{array}{l}\text { - Centre-based care } \\
\text { for children under } \\
12(24) \text { months very } \\
\text { low (4\% and } 6 \%) \\
\text { - Mainly informal } \\
\text { care (about 39\% } \\
\text { and } 41 \%)\end{array}$ \\
\hline $\begin{array}{l}\text { Baker and } \\
\text { Milligan } \\
(2011)\end{array}$ & $\begin{array}{l}\text { Canada: } \\
\text { National Longi- } \\
\text { tudinal Study } \\
\text { of Children and } \\
\text { Youth (NLSCY); } \\
\text { about 2,000 } \\
\text { children per } \\
\text { cohort }\end{array}$ & - See Baker and Milligan (2010) & $\begin{array}{l}\text { SR effects: } \\
\text { - At ages } 4 \text { or } 5 \\
\text { - Cognitive development } \\
\text { (e.g., Peabody Picture } \\
\text { Vocabulary or Number } \\
\text { Knowledge Test) } \\
\text { - Parent-reported behav- } \\
\text { ioural development (e.g., } \\
\text { hyperactivity) }\end{array}$ & $\begin{array}{l}\text { See Baker and } \\
\text { Milligan }(2010)\end{array}$ & $\begin{array}{l}\text { - No significant } \\
\text { positive effects } \\
\text { - Negative ef- } \\
\text { fects on some } \\
\text { cognitive out- } \\
\text { comes }\end{array}$ & $\begin{array}{l}\text { - None } \\
\text { (No differences by } \\
\text { child gender or } \\
\text { parental educa- } \\
\text { tion) }\end{array}$ & $\begin{array}{l}\text { See Baker and Milli- } \\
\text { gan }(2010)\end{array}$ \\
\hline $\begin{array}{l}\text { Carneiro, } \\
\text { Løken and } \\
\text { Salvanes } \\
(2010)\end{array}$ & $\begin{array}{l}\text { Administrative } \\
\text { register data on } \\
\text { schooling and } \\
\text { family events } \\
\text { and military } \\
\text { records (linked } \\
\text { child-parent } \\
\text { data) }\end{array}$ & $\begin{array}{l}\text { - July } 1,1977 \\
\text { - Introduction of paid PL for } 18 \\
\text { weeks ( } 4.5 \text { months) with } 100 \% \\
\text { income replacement as well as } \\
\text { extension of unpaid PL from } 3 \\
\text { to } 12 \text { months (on top of paid } \\
\text { PL) [de facto increase in PL } \\
\text { take-up from } 8 \text { to } 12 \text { months] }\end{array}$ & $\begin{array}{l}\text { MR \& LR effects: } \\
\text { - Dropout rates from high } \\
\text { school (measured at age } \\
\text { 29) } \\
\text { - College attendance } \\
\text { (measured at age 29) } \\
\text { - IQ (males aged 18-19) } \\
\text { - Teenage pregnancy } \\
\text { (females with birth be- } \\
\text { fore age 20) } \\
\text { - Height (males aged 18-19) }\end{array}$ & $\begin{array}{l}\text { Non-parametric } \\
\text { RD (1977 co- } \\
\text { hort; local linear } \\
\text { regression) and } \\
\text { non-parametric } \\
\text { RD-DID (co- } \\
\text { horts } 1977 \text { and } \\
\text { 1975) }\end{array}$ & $\begin{array}{l}\text { - Significant, } \\
\text { positive effect } \\
\text { on high school } \\
\text { graduation, } \\
\text { college attend- } \\
\text { ance and IQ } \\
\text { (males) for eli- } \\
\text { gible mothers } \\
\text { - Insignificant } \\
\text { effects when } \\
\text { including inel- } \\
\text { igible mothers }\end{array}$ & $\begin{array}{l}\text { - Yes, stronger } \\
\text { positive effects for } \\
\text { children from } \\
\text { households with } \\
\text { lower maternal } \\
\text { education (less } \\
\text { than } 10 \text { years of } \\
\text { schooling) } \\
\text { - No differences by } \\
\text { child gender or } \\
\text { pre-birth house- } \\
\text { hold income }\end{array}$ & $\begin{array}{l}\text { Extremely low } \\
\text { enrolment rates of } \\
\text { zero- to two-year- } \\
\text { olds in public child } \\
\text { care in 1977; main- } \\
\text { ly informal child } \\
\text { care through rela- } \\
\text { tives }\end{array}$ \\
\hline
\end{tabular}




\begin{tabular}{|c|c|c|c|c|c|c|c|}
\hline $\begin{array}{l}\text { Dustmann } \\
\text { and Schön- } \\
\text { berg (2010) }\end{array}$ & $\begin{array}{l}\text { Germany: } \\
\text { Administrative } \\
\text { data on public } \\
\text { schools in three } \\
\text { federal states } \\
\text { (information on } \\
\text { type of school/ } \\
\text { track and grad- } \\
\text { uation); social } \\
\text { security data on } \\
\text { educational } \\
\text { attainment }\end{array}$ & $\begin{array}{l}\text { Three reforms: } 1979,1986, \\
1992 \\
\text { - May 1, 1979: } \\
\text { Extension of paid+job protect- } \\
\text { ed PL (flat rate) from } 2 \text { to } 6 \\
\text { months } \\
\text { - January 1, 1986: } \\
\text { Extension of paid+job protect- } \\
\text { ed PL (flat rate up to month } 6 \text {; } \\
\text { means-tested from month } 7 \text { to } \\
\text { 10) from } 6 \text { to } 10 \text { months } \\
\text { January } 1,1992 \text { : } \\
\text { Extension of unpaid job pro- } \\
\text { tected PL from } 18 \text { to } 36 \\
\text { months (maternity leave pay- } \\
\text { ments up to month } 18 \text { ) }\end{array}$ & $\begin{array}{l}\text { MR \& LR effects: } \\
\text { - } 1979 \text { reform: wages and } \\
\text { educational attainment at } \\
\text { age } 28 \text { or } 29 \\
\text { - } 1986 \text { reform: Graduation } \\
\text { from academic track } \\
\text { (before age } 20 \text { ) } \\
\text { - } 1992 \text { reform: Choice of } \\
\text { school track at age } 14 \\
\text { (8th grade) } \\
\text { (most/medium/least aca- } \\
\text { demic track) }\end{array}$ & $\begin{array}{l}\text { DID and TS- } \\
\text { 2SLS } \\
\text { (RD and RD- } \\
\text { DID as robust- } \\
\text { ness check) }\end{array}$ & $\begin{array}{l}\text { - No significant } \\
\text { effects or only } \\
\text { extremely } \\
\text { small positive } \\
\text { effects } \\
\text { - Effect of ex- } \\
\text { pansion of } 18 \\
\text { to } 36 \text { months } \\
\text { even slightly } \\
\text { negative }\end{array}$ & - Not tested & $\begin{array}{l}\text { Enrolment in formal } \\
\text { day care centres low } \\
(5 \% \text { for under } 18- \\
\text { months-olds); Child } \\
\text { care mainly informal } \\
\text { through grandpar- } \\
\text { ents or other relatives } \\
(29 \%)\end{array}$ \\
\hline $\begin{array}{l}\text { Liu and } \\
\text { Nordstrom } \\
\text { Skans } \\
(2010)\end{array}$ & $\begin{array}{l}\text { Sweden: } \\
\text { Administrative } \\
\text { register data }\end{array}$ & $\begin{array}{l}\text { - August-October } 1988 \\
\text { - Extension of paid PL benefits } \\
\text { from } 12 \text { to } 15 \text { months } \\
\text { - Gradual extension by } 30 \text { days } \\
\text { in each of three consecutive } \\
\text { months in } 1988: 1 \text { st of Au- } \\
\text { gust/September/October }\end{array}$ & $\begin{array}{l}\text { MR effects: } \\
\text { - Test scores from nation- } \\
\text { al tests during last com- } \\
\text { pulsory school year } \\
\text { - Compulsory school } \\
\text { grades (GPA scores) } \\
\text { scores at age } 16\end{array}$ & $\begin{array}{l}\text { OLS regression } \\
\text { of child out- } \\
\text { comes on legal } \\
\text { number of PL } \\
\text { months (accord- } \\
\text { ing to birth } \\
\text { month of child) }\end{array}$ & $\begin{array}{l}\text { - Average effect } \\
\text { on child out- } \\
\text { comes is in- } \\
\text { significant }\end{array}$ & $\begin{array}{l}\text { - Positive effect for } \\
\text { well-educated } \\
\text { mothers (some } \\
\text { tertiary education) } \\
\text { - No differences } \\
\text { between boys and } \\
\text { girls }\end{array}$ & $\begin{array}{l}\text { Established public } \\
\text { child care system: } 40- \\
50 \% \text { of children aged } \\
1-2 \text { in formal day care } \\
\text { or family centres; only } \\
\text { few children in infor- } \\
\text { mal care }\end{array}$ \\
\hline $\begin{array}{l}\text { Würtz } \\
\text { Rasmussen } \\
(2010)\end{array}$ & $\begin{array}{l}\text { Denmark: } \\
\text { Administrative } \\
\text { register data } \\
\text { (linked child- } \\
\text { parent data); } \\
\text { PISA 2000 }\end{array}$ & $\begin{array}{l}\text { - March 26, } 1984 \\
\text { - Extension of paid PL from } 14 \\
\text { to } 20 \text { weeks }\end{array}$ & $\begin{array}{l}\text { MR effects: } \\
\text { - High school enrolment } \\
\text { - High school GPA } \\
\text { - Reading test scores of 15- } \\
\text { year-old students (PISA } \\
\text { test in 2000) }\end{array}$ & $\begin{array}{l}\text { RD } \\
\text { (DID as robust- } \\
\text { ness check) }\end{array}$ & $\begin{array}{l}\text { - No significant } \\
\text { effects }\end{array}$ & $\begin{array}{l}\text { None } \\
\text { (No differences } \\
\text { by child gender or } \\
\text { parental educa- } \\
\text { tion) }\end{array}$ & $\begin{array}{l}\text { Publicly subsidized } \\
\text { day care system even } \\
\text { for very young chil- } \\
\text { dren available }\end{array}$ \\
\hline
\end{tabular}

Notes: PL - Parental leave; RD - Regression Discontinuity; DID - Difference-in-Difference; TS-2SLS - Two-Sample Two-Stage-Least-Squares; IV - Instrumental Varia-

bles; GPA - Grade Point Average; SR/MR/LR - short-run/medium-run/long-run effects 


\section{Table A 2: Female employment ratio by highest education completed, Census Aus- tria 1991}

\begin{tabular}{|c|c|c|c|c|c|}
\hline \multirow[b]{2}{*}{ ISCED } & \multirow[b]{2}{*}{ Highest education completed } & \multicolumn{2}{|c|}{ Born in Austria } & \multicolumn{2}{|c|}{ Born anywhere } \\
\hline & & $\begin{array}{c}\text { Employment } \\
\text { ratio }\end{array}$ & $\mathbf{N}$ & $\begin{array}{c}\text { Employment } \\
\text { ratio }\end{array}$ & $\mathbf{N}$ \\
\hline \multicolumn{6}{|c|}{ 1. Group of mothers with lower labour force participation } \\
\hline \multirow{2}{*}{$\begin{array}{l}2 \\
3 \mathrm{C}\end{array}$} & Compulsory secondary school & $60.8 \%$ & 2,020 & $57.2 \%$ & 2,528 \\
\hline & $\begin{array}{l}\text { Intermediate technical \& voca- } \\
\text { tional secondary school (short } \\
\text { form) }\end{array}$ & $67.7 \%$ & 136 & $67.2 \%$ & 137 \\
\hline $3 \mathrm{~B}$ & Upper secondary & $75.3 \%$ & 3,828 & $74.6 \%$ & 3,970 \\
\hline \multirow[t]{2}{*}{$3 \mathrm{~A}$} & $\begin{array}{l}\text { Higher general secondary } \\
\text { school }\end{array}$ & $65.9 \%$ & 437 & $60.8 \%$ & 523 \\
\hline & Total & $70.0 \%$ & 6,421 & $67.3 \%$ & 7,158 \\
\hline
\end{tabular}

\section{Group of mothers with higher labour force participation}
Post-secondary (not tertiary)
(Intermediate or higher tech- nical \& vocational secondary school)

$81.7 \%$

699

$79.7 \%$

$5 \mathrm{~B}$

$\begin{array}{lcccc}\begin{array}{l}\text { Post-secondary college (ter- } \\ \text { tiary) }\end{array} & 90.7 \% & 333 & 90.0 \% & 341 \\ \begin{array}{l}\text { University, Polytechnic (ter- } \\ \text { tiary) }\end{array} & 81.6 \% & 305 & 76.8 \% & 358 \\ \text { Total } & 83.9 \% & 1,337 & 81.4 \% & 1,443\end{array}$

Notes: Subsample of all mothers aged 18 to 39 years with a child younger than one year (Austria, Census date May 15, 1991). The ,employment ratio" is calculated as the ratio of persons working for an employer, self-employed persons, unpaid workers engaged in the production of economic goods, and persons who have a job but are temporarily absent for some reason (e.g. maternity or parental leave) divided by the total number of people in this age group. Employment measure does not include unemployed individuals, since the focus of the following analysis is on working mothers. Including unemployed women in the employment measure changes the ratios only slightly (they become larger). The educational classification is according to ISCED 1997. Source: Census Austria 1991 (Minnesota Population Center. 2011. Integrated Public Use Microdata Series, International: Version 6.1 [Machine-readable database]. Minneapolis: University of Minnesota. Original data provided by the National Bureau of Statistics, Austria.); own calculations. 
Table A 3: RD-DID estimates controlling for school programme

\begin{tabular}{|c|c|c|c|}
\hline & $\begin{array}{c}\text { Full sample } \\
(1)\end{array}$ & $\begin{array}{l}\text { High Educ. } \\
\text { Mothers } \\
(2)\end{array}$ & $\begin{array}{l}\text { Low Educ. } \\
\text { Mothers } \\
\text { (3) }\end{array}$ \\
\hline & & BOYS + GIRLS & \\
\hline Mathematics & $\begin{array}{c}5.8 \\
(4.6)\end{array}$ & $\begin{array}{c}20.3 * * * \\
(6.7)\end{array}$ & $\begin{array}{l}-1.8 \\
(6.6)\end{array}$ \\
\hline Reading & $\begin{array}{l}-0.5 \\
(6.3)\end{array}$ & $\begin{array}{c}24.8^{* *} \\
(10.2)\end{array}$ & $\begin{array}{c}-13.3^{*} \\
(6.6)\end{array}$ \\
\hline \multirow[t]{2}{*}{ Science } & $\begin{array}{c}5.8 \\
(5.6)\end{array}$ & $\begin{array}{c}26.3 * * * \\
(7.8)\end{array}$ & $\begin{array}{l}-5.1 \\
(6.8)\end{array}$ \\
\hline & & BOYS & \\
\hline Mathematics & $\begin{array}{c}6.5 \\
(6.2)\end{array}$ & $\begin{array}{c}19.0 * * \\
(8.8)\end{array}$ & $\begin{array}{l}-1.6 \\
(9.3)\end{array}$ \\
\hline Reading & $\begin{array}{l}-1.8 \\
(8.3)\end{array}$ & $\begin{array}{c}32.9 * * \\
(14.4)\end{array}$ & $\begin{array}{c}-19.9^{*} \\
(9.7)\end{array}$ \\
\hline \multirow[t]{2}{*}{ Science } & $\begin{array}{c}4.5 \\
(7.3)\end{array}$ & $\begin{array}{c}41.7 * * * \\
(9.2)\end{array}$ & $\begin{array}{l}-16.3 \\
(10.1)\end{array}$ \\
\hline & & GIRLS & \\
\hline Mathematics & $\begin{array}{c}6.0 \\
(6.8)\end{array}$ & $\begin{array}{c}17.7 \\
(12.1)\end{array}$ & $\begin{array}{l}-1.1 \\
(9.1)\end{array}$ \\
\hline Reading & $\begin{array}{c}0.2 \\
(9.4)\end{array}$ & $\begin{array}{c}15.9 \\
(16.9)\end{array}$ & $\begin{array}{l}-6.7 \\
(8.6)\end{array}$ \\
\hline Science & $\begin{array}{c}7.8 \\
(8.2)\end{array}$ & $\begin{array}{c}7.9 \\
(12.7)\end{array}$ & $\begin{array}{c}7.3 \\
(9.9)\end{array}$ \\
\hline $\begin{array}{l}\text { Controls } \\
\text { Parental background } \\
\text { School programme }\end{array}$ & $\begin{array}{l}\checkmark \\
\checkmark\end{array}$ & $\begin{array}{l}\checkmark \\
\checkmark\end{array}$ & $\begin{array}{l}\checkmark \\
\checkmark\end{array}$ \\
\hline
\end{tabular}

Notes: The reported estimated treatment effects stem from separate estimations of different specifications. The regressions are based on different subsamples of all children born between May 1 and August 31 of 1987 or 1990. All regressions include dummy variable controls for survey year, birth months and for all children born post June. The control variables on parental background include dummy variables for mother"s and father"s educational attainment, school location, migration background and for the five different school types. The sample size for the pooled samples (top panel; row 1 and 3) are 2,840 and 1,386 respectively. Robust standard errors in parentheses (clustered by school programme, school location, and gender). Estimations weighted by individual inverse probability weights provided in the PISA data set. ${ }^{* * *} \mathrm{p}<0.01,{ }^{* *} \mathrm{p}<0.05, * \mathrm{p}<0.1$. Source: PISA data set (OECD), own calculations. 
Table A 4: RD-DID estimations excluding observations from Vienna.

\begin{tabular}{|c|c|c|c|c|c|c|}
\hline & \multicolumn{3}{|c|}{ High Educ. Mothers } & \multicolumn{3}{|c|}{ Low Educ. Mothers } \\
\hline & $\begin{array}{c}(1) \\
\text { Mar-Oct }\end{array}$ & $\begin{array}{c}(2) \\
\text { Apr-Sep }\end{array}$ & $\begin{array}{c}(3) \\
\text { May-Aug }\end{array}$ & $\begin{array}{c}(4) \\
\text { Mar-Oct }\end{array}$ & $\begin{array}{c}5) \\
\text { Apr-Sep }\end{array}$ & $\begin{array}{c}(6) \\
\text { May-Aug }\end{array}$ \\
\hline & \multicolumn{3}{|c|}{ BOYS + GIRLS } & \multicolumn{3}{|c|}{ BOYS + GIRLS } \\
\hline Mathematics & $\begin{array}{c}8.2 \\
(8.6)\end{array}$ & $\begin{array}{l}12.8 \\
(8.6)\end{array}$ & $\begin{array}{c}18.7 \\
(11.5)\end{array}$ & $\begin{array}{c}3.0 \\
(6.9)\end{array}$ & $\begin{array}{c}3.3 \\
(7.8)\end{array}$ & $\begin{array}{c}0.2 \\
(9.7)\end{array}$ \\
\hline Reading & $\begin{array}{c}15.4 \\
(10.8)\end{array}$ & $\begin{array}{l}20.4^{*} \\
(11.4)\end{array}$ & $\begin{array}{c}30.1^{* *} \\
(14.4)\end{array}$ & $\begin{array}{l}-4.6 \\
(7.4)\end{array}$ & $\begin{array}{l}-4.2 \\
(8.0)\end{array}$ & $\begin{array}{l}-4.9 \\
(8.8)\end{array}$ \\
\hline Science & $\begin{array}{c}12.6 \\
(10.0)\end{array}$ & $\begin{array}{c}18.0 \\
(10.8)\end{array}$ & $\begin{array}{l}24.8^{*} \\
(12.5)\end{array}$ & $\begin{array}{l}-1.2 \\
(7.4)\end{array}$ & $\begin{array}{l}-1.3 \\
(7.8)\end{array}$ & $\begin{array}{l}-1.4 \\
(9.1)\end{array}$ \\
\hline \multirow[t]{2}{*}{ Observations } & 1,569 & 1,188 & 787 & 3,285 & 2,478 & 1,669 \\
\hline & \multicolumn{3}{|c|}{ BOYS } & \multicolumn{3}{|c|}{ BOYS } \\
\hline Mathematics & $\begin{array}{c}15.8 \\
(12.8)\end{array}$ & $\begin{array}{c}17.1 \\
(11.9)\end{array}$ & $\begin{array}{c}15.9 \\
(15.9)\end{array}$ & $\begin{array}{c}3.1 \\
(9.1)\end{array}$ & $\begin{array}{c}6.1 \\
(9.9)\end{array}$ & $\begin{array}{c}1.9 \\
(10.9)\end{array}$ \\
\hline Reading & $\begin{array}{c}32.5^{* *} \\
(13.6)\end{array}$ & $\begin{array}{c}36.8^{* *} \\
(14.1)\end{array}$ & $\begin{array}{l}42.0^{* *} \\
(16.7)\end{array}$ & $\begin{array}{l}-12.5 \\
(10.9)\end{array}$ & $\begin{array}{l}-11.8 \\
(12.4)\end{array}$ & $\begin{array}{l}-15.6 \\
(11.6)\end{array}$ \\
\hline Science & $\begin{array}{c}35.2^{* * * *} \\
(12.2)\end{array}$ & $\begin{array}{c}40.4^{* * * *} \\
(12.7)\end{array}$ & $\begin{array}{c}44.3^{* * *} \\
(14.2)\end{array}$ & $\begin{array}{l}-9.6 \\
(9.6)\end{array}$ & $\begin{array}{l}-7.1 \\
(9.3)\end{array}$ & $\begin{array}{c}-9.2 \\
(10.8)\end{array}$ \\
\hline \multirow[t]{2}{*}{ Observations } & 784 & 586 & 391 & 1,590 & 1,205 & 824 \\
\hline & \multicolumn{3}{|c|}{ GIRLS } & \multicolumn{3}{|c|}{ GIRLS } \\
\hline Mathematics & $\begin{array}{c}6.7 \\
(10.7)\end{array}$ & $\begin{array}{c}11.0 \\
(11.8)\end{array}$ & $\begin{array}{c}24.2 \\
(16.9)\end{array}$ & $\begin{array}{c}2.7 \\
(9.4)\end{array}$ & $\begin{array}{c}0.8 \\
(10.8)\end{array}$ & $\begin{array}{c}-2.3 \\
(14.9)\end{array}$ \\
\hline Reading & $\begin{array}{c}-1.8 \\
(15.2)\end{array}$ & $\begin{array}{c}3.7 \\
(15.2)\end{array}$ & $\begin{array}{c}20.1 \\
(20.8)\end{array}$ & $\begin{array}{c}5.6 \\
(10.0)\end{array}$ & $\begin{array}{c}2.5 \\
(11.0)\end{array}$ & $\begin{array}{c}0.5 \\
(15.0)\end{array}$ \\
\hline Science & $\begin{array}{c}-4.0 \\
(12.9)\end{array}$ & $\begin{array}{c}-0.9 \\
(13.8)\end{array}$ & $\begin{array}{c}9.8 \\
(17.7)\end{array}$ & $\begin{array}{c}8.5 \\
(10.8)\end{array}$ & $\begin{array}{c}5.8 \\
(12.0)\end{array}$ & $\begin{array}{c}6.5 \\
(14.7)\end{array}$ \\
\hline Observations & 785 & 602 & 396 & 1,695 & 1,273 & 845 \\
\hline \multicolumn{7}{|c|}{$\begin{array}{l}\text { Notes: The reported estimated treatment effects stem from separate estimations of different specifications } \\
\text { based on the Austrian PISA data } 2006 \text { and } 2003 \text {. The sample excludes children living in Vienna. All } \\
\text { regressions include dummy variables for month of birth, a year dummy for } 2006 \text {, a dummy variable for } \\
\text { all children born after June. The control variables on parental background include dummy variables for } \\
\text { father"s educational attainment, school location, and migration background of the family. Robust standard } \\
\text { errors in parentheses (clustered by school programme, school location, and gender). Estimations weighted } \\
\text { by individual inverse probability weights provided in the PISA data set. }{ }^{* *} p<0.01,{ }^{* *} p<0.05,{ }^{*} p<0.1 \\
\text { Source: PISA data set (OECD), own calculations. }\end{array}$} \\
\hline
\end{tabular}


Table A 5: RD-DID estimates based on sample adding more pre-reform birth months while holding the number of post-reform birth months constant

\begin{tabular}{|c|c|c|c|c|c|c|}
\hline & \multicolumn{3}{|c|}{ High Educ. Mothers } & \multicolumn{3}{|c|}{ Low Educ. Mothers } \\
\hline & $\begin{array}{c}\text { (1) } \\
\text { Mar-Aug }\end{array}$ & $\begin{array}{c}(2) \\
\text { Apr-Aug }\end{array}$ & $\begin{array}{c}\text { (3) } \\
\text { May-Aug }\end{array}$ & $\begin{array}{c}\text { (4) } \\
\text { Mar-Aug }\end{array}$ & $\begin{array}{c}\text { (5) } \\
\text { Apr-Aug }\end{array}$ & $\begin{array}{c}\text { (6) } \\
\text { May-Aug }\end{array}$ \\
\hline & \multicolumn{3}{|c|}{ BOYS + GIRLS } & \multicolumn{3}{|c|}{ BOYS + GIRLS } \\
\hline Mathematics & $\begin{array}{c}6.0 \\
(7.7)\end{array}$ & $\begin{array}{l}10.4 \\
(7.4)\end{array}$ & $\begin{array}{l}16.4^{*} \\
(9.3)\end{array}$ & $\begin{array}{c}2.4 \\
(6.5)\end{array}$ & $\begin{array}{c}0.8 \\
(7.4)\end{array}$ & $\begin{array}{l}-5.6 \\
(9.1)\end{array}$ \\
\hline Reading & $\begin{array}{c}9.6 \\
(9.4)\end{array}$ & $\begin{array}{l}13.8 \\
(9.7)\end{array}$ & $\begin{array}{l}20.6^{*} \\
(11.7)\end{array}$ & $\begin{array}{l}-8.1 \\
(7.0)\end{array}$ & $\begin{array}{l}-9.5 \\
(7.8)\end{array}$ & $\begin{array}{c}-16.3^{*} \\
(9.2)\end{array}$ \\
\hline Science & $\begin{array}{l}12.1 \\
(8.6)\end{array}$ & $\begin{array}{l}16.6^{*} \\
(8.9)\end{array}$ & $\begin{array}{c}23.1 * * \\
(10.1)\end{array}$ & $\begin{array}{l}-3.0 \\
(7.2)\end{array}$ & $\begin{array}{l}-5.0 \\
(7.8)\end{array}$ & $\begin{array}{l}-8.8 \\
(9.1)\end{array}$ \\
\hline \multirow[t]{2}{*}{ Observations } & 1,407 & 1,178 & 943 & 2,830 & 2,367 & 1,897 \\
\hline & \multicolumn{3}{|c|}{ BOYS } & \multicolumn{3}{|c|}{ BOYS } \\
\hline Mathematics & $\begin{array}{c}13.6 \\
(11.1)\end{array}$ & $\begin{array}{l}13.6 \\
(9.8)\end{array}$ & $\begin{array}{c}15.8 \\
(12.3)\end{array}$ & $\begin{array}{l}-2.6 \\
(8.8)\end{array}$ & $\begin{array}{c}-3.1 \\
(10.2)\end{array}$ & $\begin{array}{c}-9.0 \\
(11.8)\end{array}$ \\
\hline Reading & $\begin{array}{c}27.6^{* *} \\
(11.6)\end{array}$ & $\begin{array}{l}28.9 * * \\
(12.2)\end{array}$ & $\begin{array}{l}33.1 * * \\
(15.0)\end{array}$ & $\begin{array}{l}-16.4 \\
(10.1)\end{array}$ & $\begin{array}{l}-20.2 \\
(12.2)\end{array}$ & $\begin{array}{c}-26.6^{* *} \\
(12.9)\end{array}$ \\
\hline Science & $\begin{array}{c}33.4 * * * \\
(10.5)\end{array}$ & $\begin{array}{c}35.3 * * * \\
(10.1)\end{array}$ & $\begin{array}{c}40.4^{* * *} \\
(11.4)\end{array}$ & $\begin{array}{c}-16.9 * \\
(9.7)\end{array}$ & $\begin{array}{l}-18.7 \\
(11.1)\end{array}$ & $\begin{array}{l}-23.3^{*} \\
(13.4)\end{array}$ \\
\hline \multirow[t]{2}{*}{ Observations } & 718 & 594 & 482 & 1,424 & 1,174 & 944 \\
\hline & \multicolumn{3}{|c|}{ GIRLS } & \multicolumn{3}{|c|}{ GIRLS } \\
\hline Mathematics & $\begin{array}{c}0.9 \\
(10.9)\end{array}$ & $\begin{array}{c}6.8 \\
(11.2)\end{array}$ & $\begin{array}{c}16.0 \\
(15.2)\end{array}$ & $\begin{array}{c}7.3 \\
(9.3)\end{array}$ & $\begin{array}{c}4.7 \\
(10.3)\end{array}$ & $\begin{array}{c}-2.0 \\
(13.3)\end{array}$ \\
\hline Reading & $\begin{array}{c}-8.0 \\
(14.5)\end{array}$ & $\begin{array}{c}0.1 \\
(14.8)\end{array}$ & $\begin{array}{c}13.9 \\
(19.1)\end{array}$ & $\begin{array}{c}4.1 \\
(9.3)\end{array}$ & $\begin{array}{c}2.2 \\
(10.1)\end{array}$ & $\begin{array}{c}-8.9 \\
(14.0)\end{array}$ \\
\hline Science & $\begin{array}{c}-6.8 \\
(11.7)\end{array}$ & $\begin{array}{c}-1.7 \\
(12.7)\end{array}$ & $\begin{array}{c}6.3 \\
(15.8)\end{array}$ & $\begin{array}{c}12.0 \\
(10.5)\end{array}$ & $\begin{array}{c}9.3 \\
(11.3)\end{array}$ & $\begin{array}{c}5.8 \\
(13.1)\end{array}$ \\
\hline Observations & 689 & 584 & 461 & 1,406 & 1,193 & 953 \\
\hline $\begin{array}{l}\text { otes: The reporte } \\
11 \text { regressions inc } \\
r \text { all children bor } \\
r \text { father's educat } \\
\text { andard errors in } \\
\text { eighted by indivi } \\
\end{array}$ & $\begin{array}{l}\text { al attainm } \\
\text { entheses }(c \\
\text { anverse }\end{array}$ & $\begin{array}{l}\text { tment effec } \\
\text { iables for } \mathrm{r} \\
\text { e control va } \\
\text { school loc } \\
\text { tered by sc } \\
\text { bability we }\end{array}$ & $\begin{array}{l}\text { stem from s } \\
\text { nth of birth, } \\
\text { ables on par } \\
\text { on, and mig } \\
\text { ol programn } \\
\text { ats provided }\end{array}$ & $\begin{array}{l}\text { rate estimat } \\
\text { ear dummy } \\
\text { l backgrou } \\
\text { on backgrol }\end{array}$ & $\begin{array}{l}\text { ns of differe } \\
\text { r } 2006, \text { a d } \\
\text { include dur } \\
d \text { of the fam }\end{array}$ & $\begin{array}{l}\text { specifications } \\
\text { imy variable } \\
\text { ny variables } \\
\text { y. Robust } \\
\text {.) Estimations } \\
01, * * p<0.05\end{array}$ \\
\hline
\end{tabular}


Table A 6: RD-DDD estimates, expanding the sample to the left of the cut-off

\begin{tabular}{|c|c|c|c|c|c|c|}
\hline & \multicolumn{3}{|c|}{ High Educ. Mothers } & \multicolumn{3}{|c|}{ Low Educ. Mothers } \\
\hline & $\begin{array}{c}\text { (1) } \\
\text { Mar-Aug }\end{array}$ & $\begin{array}{c}(2) \\
\text { Apr-Aug }\end{array}$ & $\begin{array}{c}\text { (3) } \\
\text { May-Aug }\end{array}$ & $\begin{array}{c}(4) \\
\text { Mar-Aug }\end{array}$ & $\begin{array}{c}5) \\
\text { Apr-Aug }\end{array}$ & $\begin{array}{c}6) \\
\text { May-Aug }\end{array}$ \\
\hline & \multicolumn{3}{|c|}{ BOYS + GIRLS } & \multicolumn{3}{|c|}{ BOYS + GIRLS } \\
\hline Mathematics & $\begin{array}{l}19.0^{*} \\
(10.0)\end{array}$ & $\begin{array}{l}21.9^{*} \\
(11.3)\end{array}$ & $\begin{array}{c}22.8 \\
(14.8)\end{array}$ & $\begin{array}{c}-5.6 \\
(10.1)\end{array}$ & $\begin{array}{c}-9.3 \\
(11.8)\end{array}$ & $\begin{array}{l}-17.1 \\
(14.1)\end{array}$ \\
\hline Reading & $\begin{array}{c}18.5 \\
(13.4)\end{array}$ & $\begin{array}{c}20.4 \\
(15.2)\end{array}$ & $\begin{array}{c}25.1 \\
(17.3)\end{array}$ & $\begin{array}{l}-22.2 * \\
(12.4)\end{array}$ & $\begin{array}{l}-25.9^{*} \\
(13.4)\end{array}$ & $\begin{array}{l}-31.0^{*} \\
(15.5)\end{array}$ \\
\hline Science & $\begin{array}{c}29.0^{* *} \\
(11.9)\end{array}$ & $\begin{array}{c}33.4 * * \\
(13.3)\end{array}$ & $\begin{array}{l}37.8^{* *} \\
(15.3)\end{array}$ & $\begin{array}{l}-14.1 \\
(11.5)\end{array}$ & $\begin{array}{l}-16.3 \\
(13.3)\end{array}$ & $\begin{array}{l}-20.9 \\
(14.8)\end{array}$ \\
\hline \multirow[t]{2}{*}{ Observations } & 3,143 & 2,645 & 2,158 & 4,877 & 4,111 & 3,325 \\
\hline & \multicolumn{3}{|c|}{ BOYS } & \multicolumn{3}{|c|}{ BOYS } \\
\hline Mathematics & $\begin{array}{c}28.3^{* *} \\
(13.1)\end{array}$ & $\begin{array}{c}32.9^{* *} \\
(13.5)\end{array}$ & $\begin{array}{c}38.1^{* *} \\
(18.2)\end{array}$ & $\begin{array}{l}-32.1^{*} \\
(16.1)\end{array}$ & $\begin{array}{l}-33.3 * \\
(17.3)\end{array}$ & $\begin{array}{c}-37.2^{* *} \\
(16.7)\end{array}$ \\
\hline Reading & $\begin{array}{l}32.1^{*} \\
(16.6)\end{array}$ & $\begin{array}{l}36.2^{*} \\
(18.2)\end{array}$ & $\begin{array}{l}40.0^{*} \\
(22.6)\end{array}$ & $\begin{array}{c}-54.0^{* *} \\
(19.9)\end{array}$ & $\begin{array}{c}-55.9^{* *} \\
(21.5)\end{array}$ & $\begin{array}{c}-57.1^{* *} \\
(22.1)\end{array}$ \\
\hline Science & $\begin{array}{c}48.5^{* * * *} \\
(10.7)\end{array}$ & $\begin{array}{c}57.0^{* * * *} \\
(12.0)\end{array}$ & $\begin{array}{c}66.9^{* * * *} \\
(15.8)\end{array}$ & $\begin{array}{c}-50.2 * * * \\
(16.7)\end{array}$ & $\begin{array}{c}-52.2 * * \\
(18.7)\end{array}$ & $\begin{array}{c}-53.1 * * * \\
(18.6)\end{array}$ \\
\hline \multirow[t]{2}{*}{ Observations } & 1,615 & 1,350 & 1,113 & 2,410 & 2,014 & 1,636 \\
\hline & \multicolumn{3}{|c|}{ GIRLS } & \multicolumn{3}{|c|}{ GIRLS } \\
\hline Mathematics & $\begin{array}{c}11.3 \\
(16.2)\end{array}$ & $\begin{array}{c}11.6 \\
(18.8)\end{array}$ & $\begin{array}{c}9.4 \\
(23.6)\end{array}$ & $\begin{array}{c}16.8 \\
(11.6)\end{array}$ & $\begin{array}{c}11.1 \\
(15.4)\end{array}$ & $\begin{array}{c}2.6 \\
(21.7)\end{array}$ \\
\hline Reading & $\begin{array}{c}1.2 \\
(18.5)\end{array}$ & $\begin{array}{c}3.6 \\
(21.4)\end{array}$ & $\begin{array}{c}13.6 \\
(21.2)\end{array}$ & $\begin{array}{c}8.6 \\
(12.8)\end{array}$ & $\begin{array}{c}2.5 \\
(16.4)\end{array}$ & $\begin{array}{c}-8.5 \\
(23.9)\end{array}$ \\
\hline Science & $\begin{array}{c}9.5 \\
(19.2)\end{array}$ & $\begin{array}{c}9.6 \\
(21.7)\end{array}$ & $\begin{array}{c}10.4 \\
(23.3)\end{array}$ & $\begin{array}{c}17.3 \\
(13.7)\end{array}$ & $\begin{array}{c}14.9 \\
(17.7)\end{array}$ & $\begin{array}{c}9.9 \\
(22.1)\end{array}$ \\
\hline Observations & 1,528 & 1,295 & 1,045 & 2,467 & 2,097 & 1,689 \\
\hline
\end{tabular}

Notes: The reported estimated treatment effects stem from separate estimations of different specifications. All regressions include dummy variables for month of birth, year and country fixed effects, a dummy variable for all children born after June, interaction effects between year and the ,post June" dummy, year and country, country and ,post Juneec. The control variables on parental background include dummy variables for father"s educational attainment, school location, and migration background of the family. Robust standard errors in parentheses (clustered by school track (more/less academic), school location, and gender). Estimations weighted by individual inverse probability weights provided in the PISA data set. *** $\mathrm{p}<0.01,{ }^{* *} \mathrm{p}<0.05, * \mathrm{p}<0.1$. Source: PISA data set (OECD), own calculations. 